\title{
Pleistocene Brawley and Ocotillo Formations: Evidence for Initial Strike-Slip Deformation Along the San Felipe and San Jacinto Fault Zones, Southern California
}

\author{
Stefan M. Kirby \\ Susanne U. Janecke \\ Rebecca J. Dorsey \\ Bernard A. Housen \\ Western Washington University, bernard.housen@wwu.edu \\ Victoria E. Langenheim \\ See next page for additional authors
}

Follow this and additional works at: https://cedar.wwu.edu/geology_facpubs

Part of the Geology Commons

\section{Recommended Citation}

Kirby, Stefan M.; Janecke, Susanne U.; Dorsey, Rebecca J.; Housen, Bernard A.; Langenheim, Victoria E.; McDougall, Kristin A.; and Steely, Alexander N., "Pleistocene Brawley and Ocotillo Formations: Evidence for Initial Strike-Slip Deformation Along the San Felipe and San Jacinto Fault Zones, Southern California" (2007). Geology Faculty Publications. 10.

https://cedar.wwu.edu/geology_facpubs/10 
Authors

Stefan M. Kirby, Susanne U. Janecke, Rebecca J. Dorsey, Bernard A. Housen, Victoria E. Langenheim, Kristin A. McDougall, and Alexander N. Steely 


\title{
Pleistocene Brawley and Ocotillo Formations: Evidence for Initial Strike-Slip Deformation along the San Felipe and San Jacinto Fault Zones, Southern California
}

\author{
Stefan M. Kirby, Susanne U. Janecke ${ }^{1}$ Rebecca J. Dorsey, ${ }^{2}$ Bernard A. Housen, ${ }^{3}$ \\ Victoria E. Langenheim, ${ }^{4}$ Kristin A. McDougall, ${ }^{5}$ and Alexander N. Steely \\ Department of Geology, 4505 Old Main Hill, Utah State University, Logan, Utah 84322-4505, U.S.A. \\ (e-mail: stefankirby@utah.gov)
}

\begin{abstract}
A B S T R A C T
We examine the Pleistocene tectonic reorganization of the Pacific-North American plate boundary in the Salton Trough of southern California with an integrated approach that includes basin analysis, magnetostratigraphy, and geologic mapping of upper Pliocene to Pleistocene sedimentary rocks in the San Felipe Hills. These deposits preserve the earliest sedimentary record of movement on the San Felipe and San Jacinto fault zones that replaced and deactivated the late Cenozoic West Salton detachment fault. Sandstone and mudstone of the Brawley Formation accumulated between $\sim 1.1$ and $\sim 0.6-0.5 \mathrm{Ma}$ in a delta on the margin of an arid Pleistocene lake, which received sediment from alluvial fans of the Ocotillo Formation to the west-southwest. Our analysis indicates that the Ocotillo and Brawley formations prograded abruptly to the east-northeast across a former mud-dominated perennial lake (Borrego Formation) at $\sim 1.1 \mathrm{Ma}$ in response to initiation of the dextral-oblique San Felipe fault zone. The $\sim 25-\mathrm{km}$-long San Felipe anticline initiated at about the same time and produced an intrabasinal basement-cored high within the San Felipe-Borrego basin that is recorded by progressive unconformities on its north and south limbs. A disconformity at the base of the Brawley Formation in the eastern San Felipe Hills probably records initiation and early blind slip at the southeast tip of the Clark strand of the San Jacinto fault zone. Our data are consistent with abrupt and nearly synchronous inception of the San Jacinto and San Felipe fault zones southwest of the southern San Andreas fault in the early Pleistocene during a pronounced southwestward broadening of the San Andreas fault zone. The current contractional geometry of the San Jacinto fault zone developed after 0.5-0.6 Ma during a second, less significant change in structural style.
\end{abstract}

Online enhancements: appendix, figures, table.

\section{Introduction}

Tectonic Setting. The Late Miocene to Recent evolution of the southern San Andreas fault system along the Pacific-North American plate boundary (fig. 1) is complex and incompletely understood. Until late Pliocene or early Pleistocene time, most of the dextral strike-slip motion was localized on

Manuscript received August 30, 2005; accepted July 19, 2006.

${ }^{1}$ Author for correspondence; e-mail: sjanecke@cc.usu.edu.

${ }^{2}$ Geological Sciences, University of Oregon, Eugene, Oregon 97403-1272, U.S.A.

${ }^{3}$ Geology, Western Washington University, Bellingham, Washington 98225 , U.S.A.

${ }^{4}$ U.S. Geological Survey, 345 Middlefield Road, Menlo Park, California 94025, U.S.A.

${ }^{5}$ Flagstaff Science Center, U.S. Geological Survey, 2255 North Gemini Drive, Flagstaff, Arizona 86001, U.S.A. the San Andreas fault at the northeastern margin of the Salton Trough (Atwater 1970; Axen and Fletcher 1998; Oskin and Stock 2003). The Late Cenozoic West Salton detachment fault in the western Salton Trough accommodated a small fraction of the Pliocene plate motion, but starting in late Pliocene or early Pleistocene time, crosscutting dextral strike-slip faults (fig. 2) replaced the West Salton detachment and began to accommodate a significant fraction of the relative motion (Sharp 1967; Frost et al. 1996; Axen and Fletcher 1998; Janecke et al. 2005b; Kirby 2005; Steely et al. 2005; Lutz et al. 2006). The San Jacinto and Elsinore faults are the most prominent and active faults in this crosscutting dextral fault zone (Sharp 1967; Sanders 


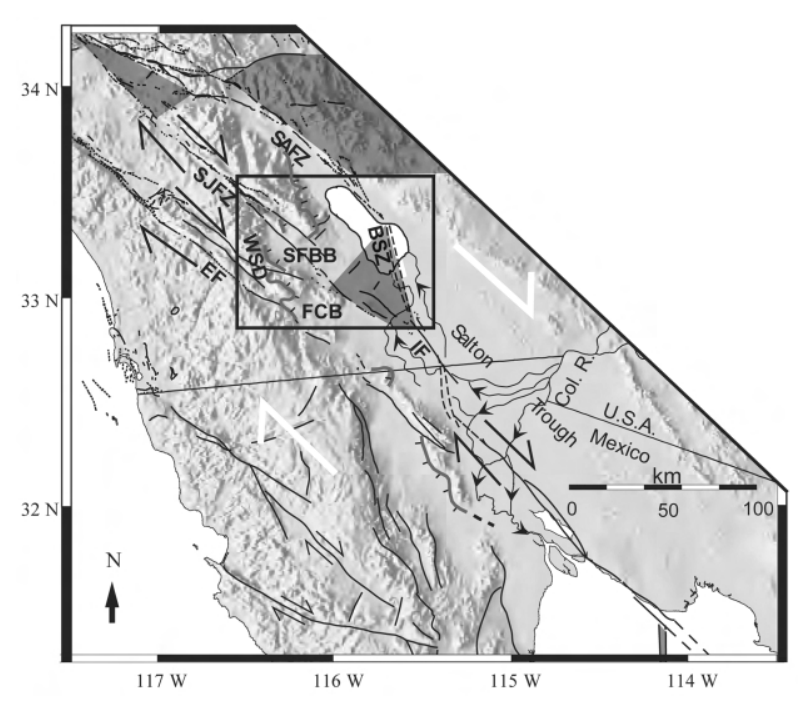

Figure 1. Tectonic map of southern California.

1989; Magistrale and Rockwell 1996), but there are many other less-continuous dextral and sinistral faults and related folds that are presently less active and may be older (fig. 1). Because Quaternary to modern slip rates across the San Jacinto fault zone may be subequal to slip rates across the southern San Andreas fault (Savage and Prescott 1976; Fialko 2006), the development of these crosscutting dextral faults represents a major redistribution of plate motion. It is important to know the age, evolution, and basinal response to these younger strike-slip faults to inform tectonic, paleogeographic, sliprate, and seismic-hazards studies of the region.

Sedimentary basins are very faithful recorders of tectonic events. The sedimentary rocks and geologic structures in the San Felipe Hills provide critical insight into the geometric and kinematic transition from Late Miocene to early Pleistocene low-angle detachment faulting to the current phase of high-angle dextral faults and wrench deformation. The San Felipe Hills are located in the San Felipe-Borrego basin, which lies between Fish Creek and the Vallecito Mountains to the south and the Santa Rosa and San Ysidro mountains to the north and west (figs. 2, 3). Strands of the San Jacinto fault zone in the study area deform and expose a Late Miocene through Quaternary sedimentary section (Dibblee 1954, 1984; Morley 1963; Bartholomew 1968; Dronyk 1977; Reitz 1977; Wagoner 1977; Feragen 1986; Wells 1987; Guthrie 1990; Heitman 2002; Lilly 2003; Kirby 2005), which records the kinematic and structural evolution of the plate boundary at this latitude. Because the sedimentary rocks exposed in the San Felipe Hills ac- cumulated during transtensional slip on the West Salton detachment fault and later dextral shear on crosscutting strike-slip faults, they contain detailed information about the tectonic transition from transtensional deformation in the Salton Trough to wrench tectonics (Janecke et al. 2005b; figs. 3-5).

Dibblee $(1954,1984)$ first noted large-scale stratigraphic relationships, including facies changes and angular unconformities, that hinted at significant changes in basin architecture during deposition of the Pleistocene rocks in the San Felipe Hills. In this article we document that the transition from slip on the West Salton detachment fault to slip on crosscutting dextral faults and concurrent transpressional folding produced significant changes in basin architecture that are recorded in the stratigraphy of the San Felipe-Borrego basin (figs. 4, 5).

This article presents the results of geologic mapping, stratigraphic and sedimentologic analyses, and magnetostratigraphic dating in the PliocenePleistocene Borrego Formation and early to middle Pleistocene Brawley and Ocotillo formations northeast of the San Felipe fault zone in the southwestern Salton Trough (fig. 2) in order to date and characterize these changes along the North American plate boundary. The study area is well suited for addressing this topic because it contains the Coyote Creek and Clark strands of the San Jacinto fault zone (figs. 2, 3), and sedimentation was nearly continuous during Pliocene and early Pleistocene time. Despite theoretical models that predict that fault zones should simplify with increasing slip (e.g., Scholz 2002), results of this study show that the southern San Andreas fault zone has become more complex and broader through time.

Structural and Stratigraphic Framework. The early syn-detachment succession exposed in the San Felipe Hills includes the marine latest Miocene through Pliocene Imperial Group and its lateral nonmarine equivalents at Borrego Mountain and the overlying Pliocene fluvial-deltaic Diablo and Olla formations of the Palm Spring Group (Dibblee 1954, 1984; Reitz 1977; Winker 1987; Winker and Kidwell 1996; Axen and Fletcher 1998; Steely et al. 2004, 2005; figs. 4, 5). The Borrego Formation is a thick Pliocene-Pleistocene unit of lacustrine mudstone, siltstone, and minor sandstone that interfingers with and conformably overlies the Diablo Formation in the San Felipe-Borrego basin. The Borrego Formation probably accumulated during the final phases of regional transtension on the West Salton detachment fault (Dorsey et al. 2004; Steely et al. 2005; Steely 2006; Kairouz 2005; figs. $4,5)$. The syn-detachment succession (Imperial Group through Borrego Formation) is up to $\sim 4200$ 


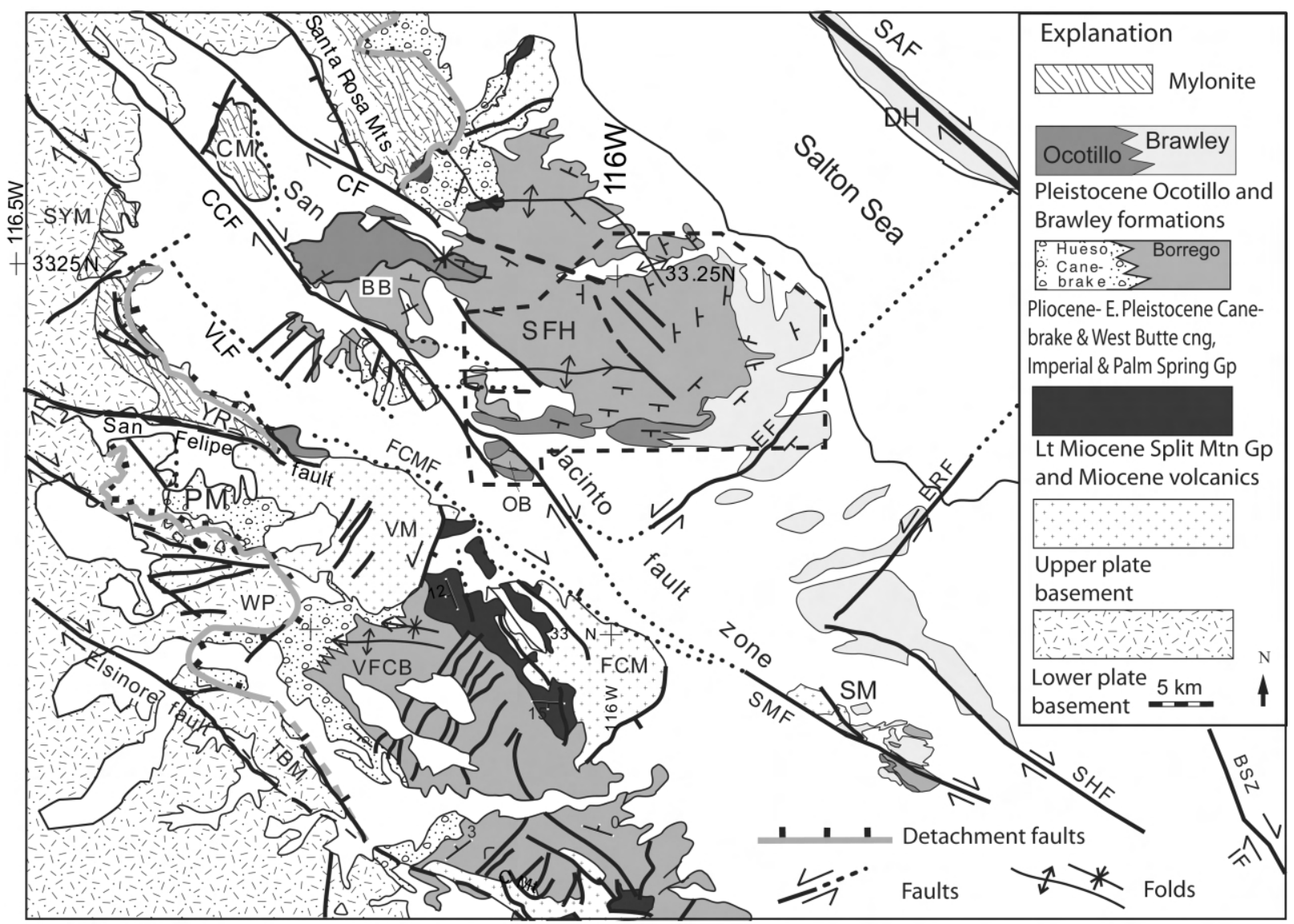

Figure 2. Geologic map of the western Salton Trough. Shape outlined by dashed black line is the extent of the study area in figure 3. $C C F$, Coyote Creek fault; $C F$, Clark fault; $S A F$, San Andreas fault; $S H F$, Superstition Hills fault; $S M F$, Superstition Mountain fault; $E F$, Extra fault and Elsinore fault; $E R F$, Elmore Ranch fault; $I F$, Imperial fault; BSZ, Brawley seismic zone; DH, Durmid Hill; SFH, San Felipe Hills; OB, Ocotillo Badlands; BB, Borrego Badlands; VFCB, Fish Creek-Vallecito basin, FCM, Fish Creek Mountains; PM, Pinyon Mountains; CM, Coyote Mountain; SYM, San Ysidro Mountains; VM, Vallecito Mountains; TBM, Tierra Blanca Mountains; VLF, Veggie line fault; WP, Whale Peak; YR, Yaqui Ridge; FCMF, Fish Creek Mountain fault; $S M$, Superstition Mountains. Modified extensively from Axen and Fletcher (1998).

$\mathrm{m}$ thick in the San Felipe-Borrego subbasin (Dibblee 1954, 1984; Morley 1963; Dronyk 1977; Reitz 1977; Wagoner 1977; Feragen 1986; Wells 1987; Heitman 2002; Lilly 2003; Kirby 2005; Steely 2006; figs. 2-4).

The top of the fine-grained Borrego Formation is marked by an abrupt change in lithology and sedimentary environment at the base of the coarsergrained Ocotillo and Brawley formations (Dibblee 1954, 1984; Morley 1963; Dronyk 1977; Reitz 1977; Wagoner 1977; Feragen 1986; Wells 1987; Dorsey 2002; Heitman 2002; Lilly 2003; Kirby 2005; Kirby et al. 2004; Lutz 2005; Lutz et al. 2006; this study; figs. 4, 5). The Ocotillo Formation and its finergrained lateral equivalent, the Brawley Formation, overlie a contact that changes laterally from an an- gular unconformity to a conformable contact (Dibblee 1954, 1984; figs. 2, 3). Previous workers have inconsistently described this contact and its character, location, and tectonic significance in and near the San Felipe Hills (Dibblee 1954, 1984; Morley 1963; Bartholomew 1968, 1970; Dronyk 1977; Reitz 1977; Wagoner 1977; Feragen 1986; Wells 1987; Brown et al. 1991; Remeika and Beske-Diehl 1996; Heitman 2002; Lilly 2003; Lutz 2005; Lutz et al. 2006).

The sedimentology and depositional environment of the Brawley Formation were also poorly known before this study. Dibblee $(1954,1984)$ briefly described the Brawley as the lacustrine lateral equivalent of the Ocotillo Formation and stated that it is lithologically indistinguishable 


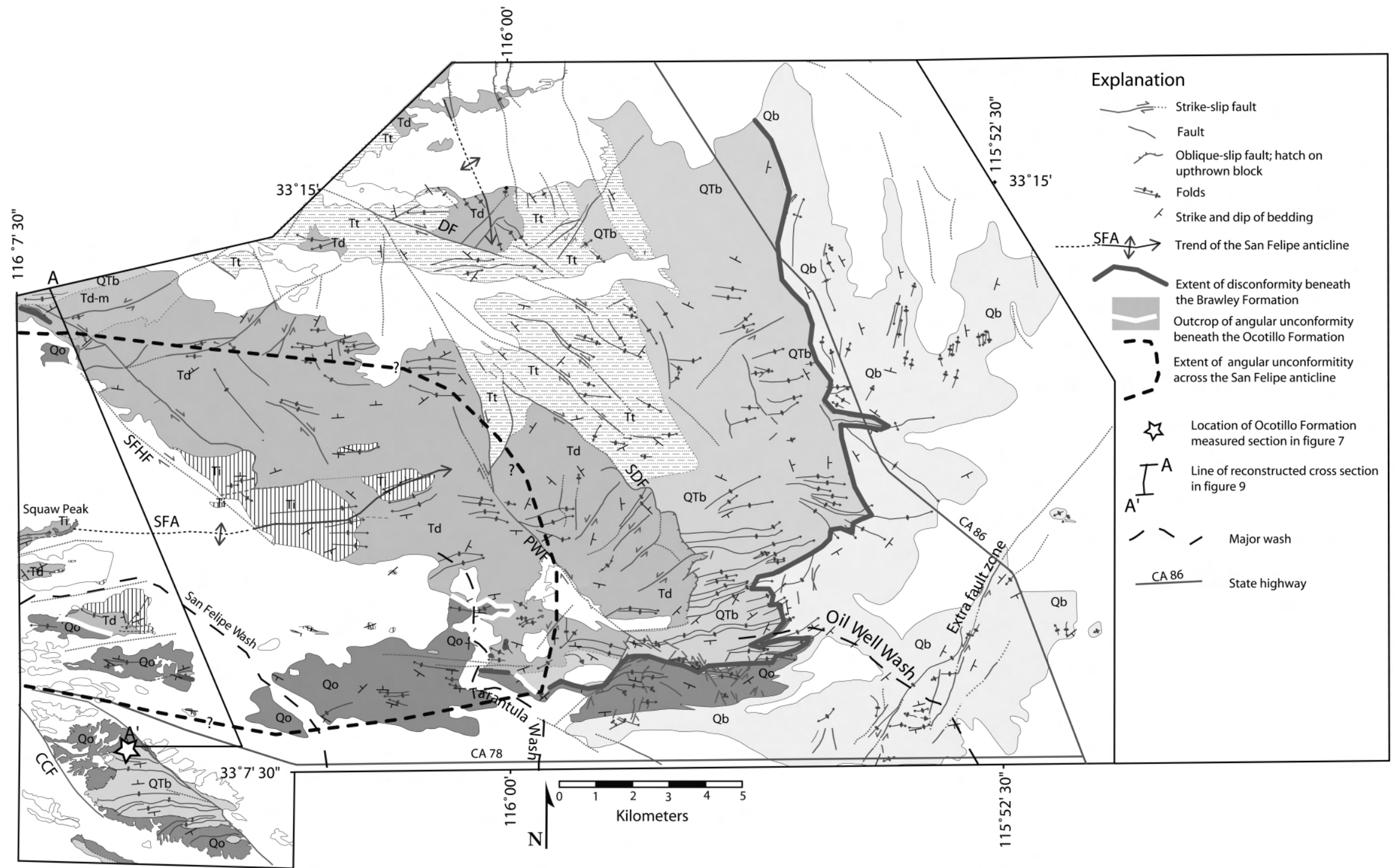

Figure 3. Simplified geologic map of the San Felipe Hills compiled from a plate in Kirby (2005) and including mapping of Lilly (2003). Major strike-slip faults within the study area include the Coyote Creek fault $(C C F)$, Dump fault $(D F)$, Extra fault, Powerline fault $(P W F)$, Sand Dunes fault $(S D F)$, and San Felipe Hills fault $(S F H F)$. Unit abbreviations are given in figure 4. 


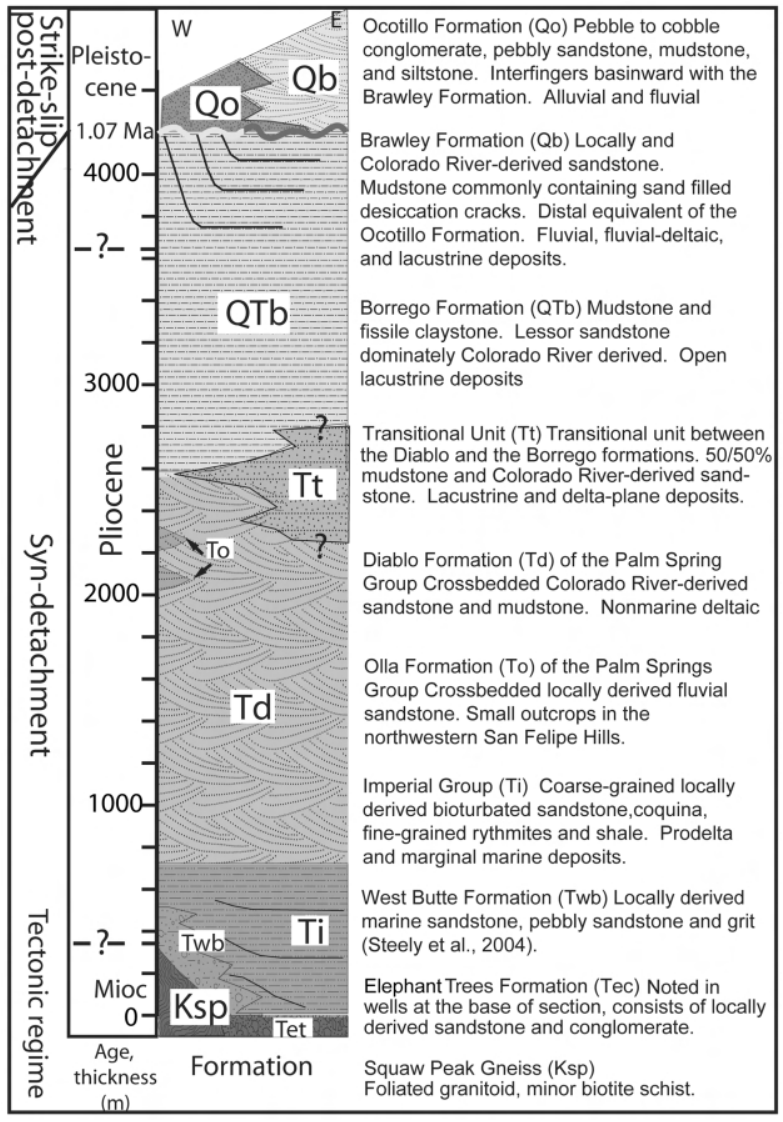

Figure 4. Stratigraphic column. Early syn-detachment units are the Imperial Group to Diablo Formation. The Borrego Formation was probably deposited late during slip on the detachment fault. Above these units, across an angular unconformity (lighter shading) in the west and disconformity (darker shading) in the east are the Ocotillo and Brawley formations, which were likely deposited after initial slip on strands of the San Jacinto and San Felipe fault zones. The $\sim 1.1-\mathrm{Ma}$ age of the unconformity was determined paleomagnetically. Other ages are approximate from this study and from Johnson et al. (1983), Remeika and Beske-Diehl (1996), Winker and Kidwell (1996), and Steely et al. (2004). Thicknesses are minima based on mapping from this study.

from the underlying Borrego Formation where a thin basal conglomerate bed is absent beneath the Brawley Formation. Later workers mostly accepted Dibblee's (1954, 1984) environmental and lithologic interpretation of the Brawley Formation in the San Felipe Hills and focused instead on structural relationships (e.g., Dronyk 1977; Wagoner 1977; Wells 1987; Feragen 1986).

The structures controlling basin subsidence and sedimentation in the southwestern Salton Trough have evolved through time and can be subdivided into two distinct phases (fig. 5). Development of the first large basins of the Salton Trough was controlled by oblique, top-to-the-east slip on the West Salton detachment fault in the west-southwest (Axen and Fletcher 1998; Winker and Kidwell 2002; Steely et al. 2004; Kairouz 2005). Later, by latest Pliocene to Pleistocene time, crosscutting strikeslip faults, and eventually the modern San Jacinto fault zone, were the primary controls on basin architecture in the San Felipe-Borrego basin (Janecke et al. 2005b; Kirby 2005; Lutz 2005; Steely et al. 2005; Lutz et al. 2006).

The San Felipe Hills are bounded and deformed by strike-slip faults (Dibblee 1954, 1984; Sharp 1967). The Clark fault enters the study area from the northwest, the San Felipe Hills and Coyote Creek faults lie along the southwestern margin, and the sinistral Extra fault defines the southeast margin of the San Felipe Hills (Kirby 2005; figs. 2, 3). Slip on these dextral fault strands has created many closely spaced folds throughout the San Felipe Hills (Dibblee 1984; Heitman 2002; Lilly 2003; Kirby 2005; fig. 3).

\section{Results}

Distribution of Pleistocene Sedimentary Rocks. A new geologic map of the San Felipe Hills shows the distribution of late Cenozoic rocks, rapid eastward fining of the Ocotillo Formation into the Brawley Formation, and the conformable to angular contacts beneath the Ocotillo and Brawley formations (fig. 3; Kirby 2005; this study). The Ocotillo and Brawley formations are exposed throughout the southern and eastern portions of the San Felipe Hills and locally in the northwest (figs. 2, 3). The Brawley Formation is also present in the subsurface east and south of the San Felipe Hills (Dibblee 1984; Herzig et al. 1988). In the southeast part of the San Felipe Hills, east of the Powerline fault, the Brawley Formation interfingers with, grades laterally west into, and overlies the Ocotillo Formation (Dibblee 1954, 1984; this study; figs. 2, 3). The contact between the two units is placed above the highest conglomerate or pebbly sandstone (G. Girty, personal communication, 2003; this study). A thin (5$25 \mathrm{~m}$ ), widespread tongue of conglomerate and pebbly sandstone, mapped as Ocotillo Formation, underlies the finer-grained Brawley Formation in the southeastern San Felipe Hills (Dibblee 1954, 1984; Heitman 2002; Lilly 2003; this study; figs. 3, 4). This conglomerate fines northward into locally derived basal sandstone and sandy granule conglomerate of the Brawley Formation.

The Ocotillo, Brawley, and uppermost Borrego 


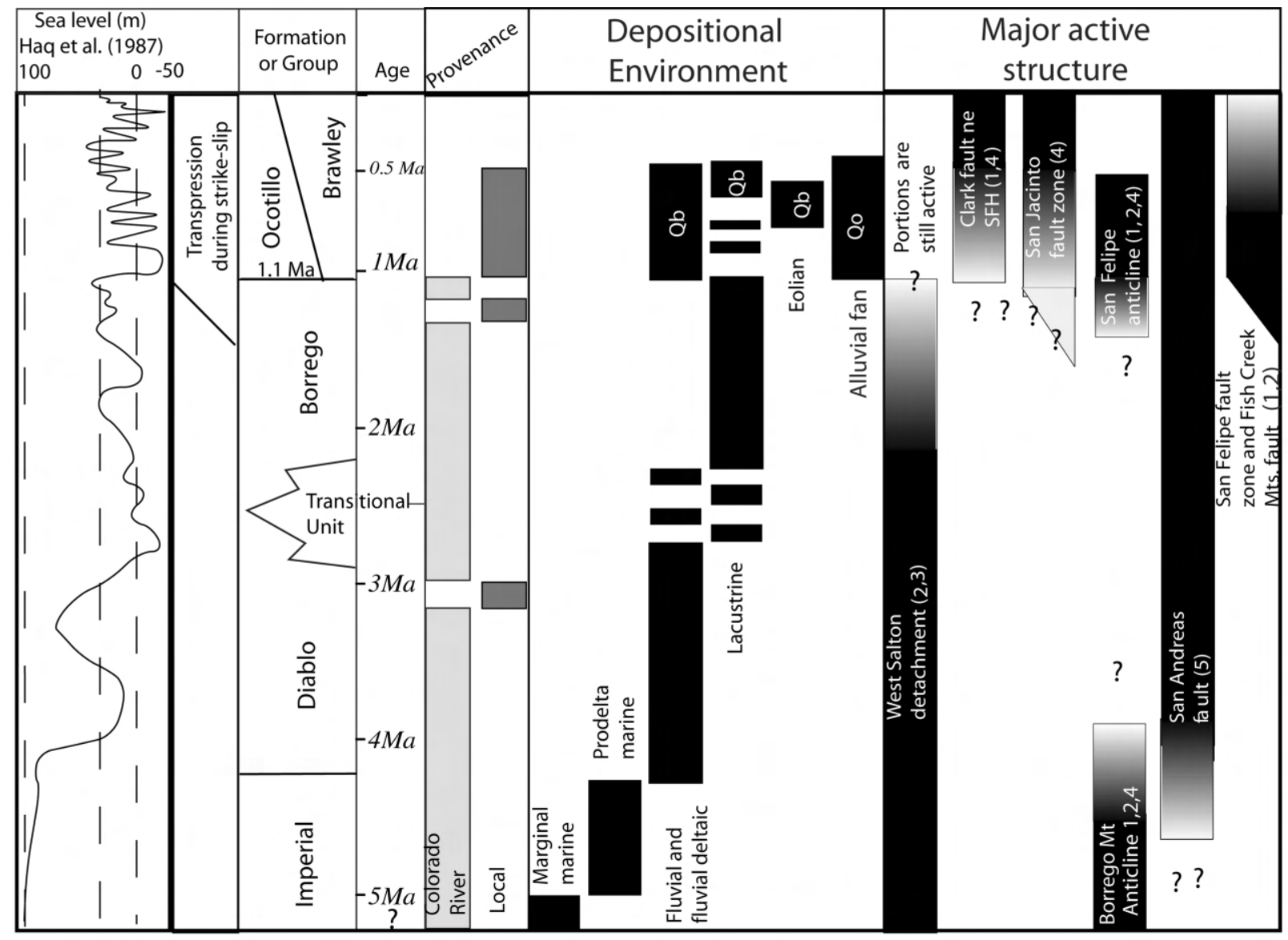

Figure 5. Tectonic and stratigraphic summary. Units and their approximate ages are shown to the left. Italics represent inferred ages primarily from correlation with paleomagnetically dated units to the south in the Fish Creek Basin (Opdyke et al. 1977; Johnson et al. 1983; Winker and Kidwell 1996). Regular type represents ages constrained by this study. Fault activity indicates the major structures that probably controlled the basin's architecture. Numbers represent data source (1, this study; 2, Steely 2006; 3, Axen and Fletcher 1998; Dorsey and Janecke 2002; Winker and Kidwell 2002; 4, Matti and Morton 1993; Morton and Matti 1993; Janecke et al. 2004, 2005a; Lutz et al. 2006; 5 , Oskin and Stock 2003).

formations were described in this study through detailed field observations and measurement of two stratigraphic sections (figs. 6, 7). The section along Oil Well Wash (625 m thick; fig. 6) in the southeast San Felipe Hills (fig. 3) is the site of our magnetostratigraphic study. It is located $21 \mathrm{~km}$ eastnortheast of a second measured section in the Ocotillo Badlands (star on fig. 3; $224 \mathrm{~m}$ thick), which describes the uppermost Borrego Formation and the lower half of the overlying Ocotillo Formation (fig. 7).

Borrego Formation. The Borrego Formation is up to $1700 \mathrm{~m}$ thick in the eastern San Felipe Hills (fig. 4). The Borrego Formation consists of red laminated to massive claystone, mudstone, and siltstone with lesser sandstone and marlstone (figs. 6, 7). Sand- stone beds in the Borrego Formation are up to $4 \mathrm{~m}$ thick and are composed dominantly of sublitharenite derived from the Colorado River (C-suite composition of Winker 1987). Rare beds of pebbly sandstone and conglomerate with tonalite clasts, and one coarse bed with oyster shell fragments derived from the marine Imperial Group, are found in the middle to upper Borrego Formation. Sandstone derived from local sources (typically tonalite) is called L-suite (Winker 1987). At Oil Well Wash, the upper $5 \mathrm{~m}$ of the Borrego Formation consists of interbedded very fine-grained sandstone, siltstone, and very thin beds $(1-2 \mathrm{~cm})$ of laminated micrite (fig. 6). There are no soil structures or desiccation cracks in the uppermost Borrego Formation.

Microfossils in the Borrego Formation include os- 


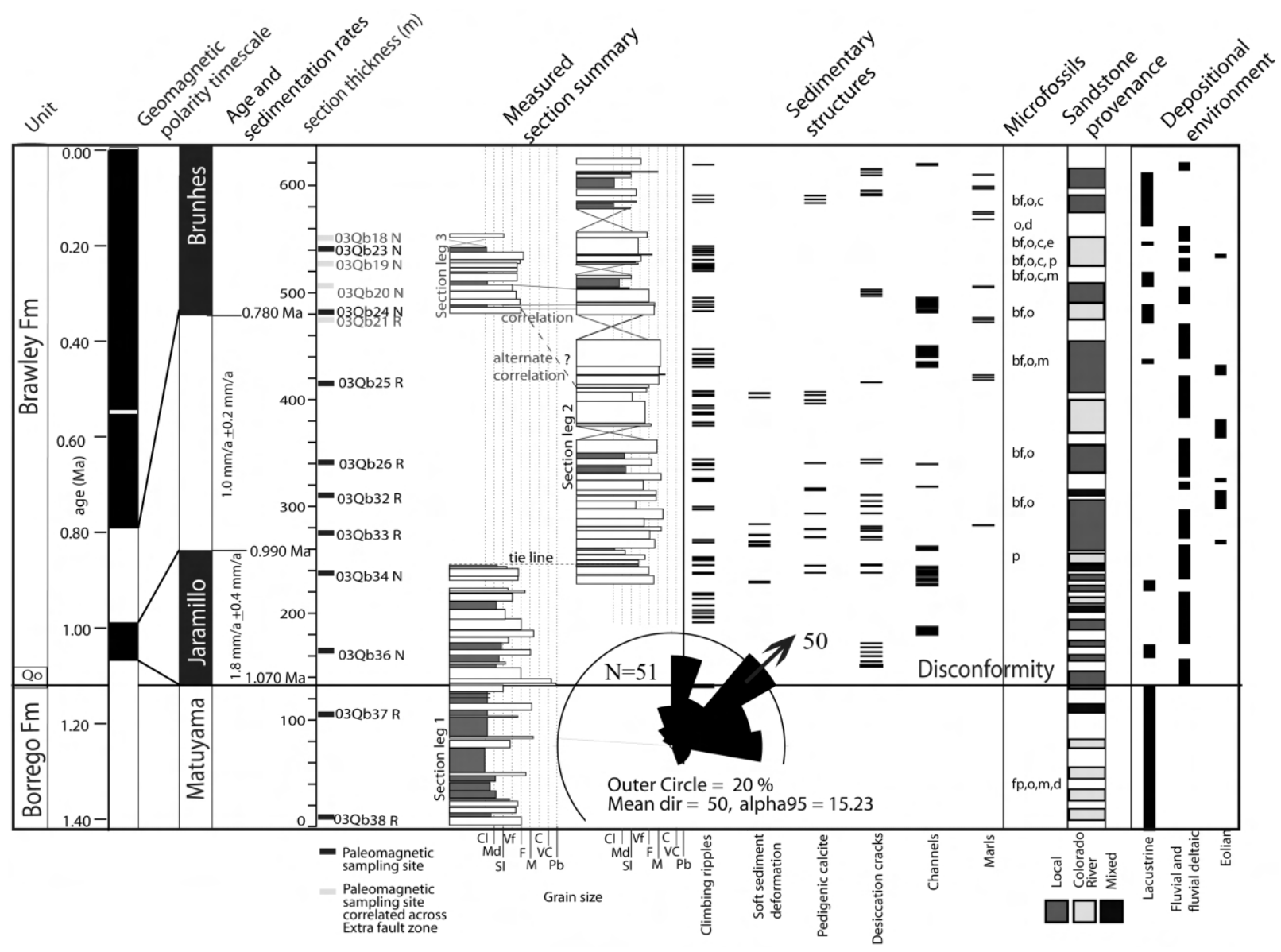

Figure 6. Measured section at Oil Well Wash. Age constraints are shown relative to provenance, depositional environment, and sedimentary structures. Disconformity (black line) separates the Ocotillo and Brawley formations from the underlying Borrego Formation. Base of the Jaramillo normal subchron was placed at the disconformity because of magnetostratigraphy in the Borrego Badlands (Lutz et al. 2006). The base of the Brunhes normal was placed at $480 \mathrm{~m}$ based on stratigraphic correlation of leg 2 and 3 across the Extra fault zone. The thin dashed line is position of the other possible correlation, which is not preferred because of stratigraphic mismatches. Microfossils include $b f$, benthic foraminifers; $c$, chara; $d$, diatoms; $e$, echinoids; $f p$, planktonic foraminifers; $m$, mollusks; $o$, ostracods; $p$, plant fragments. Reference polarity timescale is from Cande and Kent (1995). Paleocurrents are from the Brawley Formation throughout the eastern San Felipe Hills. Mean direction $=50^{\circ}$. Paleoflow was measured from channel fill structures similar to the one shown in figure A1D, available in the online edition or from the Journal of Geology office. Grain size and patterns are explained in figure 7.

tracods, micromollusks, diatoms, rare planktonic foraminifers, and plant fragments (fig. 6; table A1, available in the online edition or from the Journal of Geology office). The faunal assemblage indicates freshwater to occasionally brackish-saline lacustrine conditions, dominated by quiet and relatively clear, shallow $(<20 \mathrm{~m})$, nearshore environments in a pool/lacustrine and/or lagoonal setting. Water for this system apparently was provided by both freshwater and saline (possibly marine) sources.

The dominantly clay to silty grain size of the Borrego Formation, ubiquitous laminations, rare sedimentary structures, rare desiccation cracks, near absence of soil and root horizons, and abundant lacustrine microfossils indicate that the Borrego Formation accumulated in a perennial lake. Sandstone and pebbly beds in the southwestern Borrego Badlands (fig. 2) represent more proximal facies and deltaic nearshore environments. To the east, in the San Felipe Hills (figs. 2, 3), claystone, mudstone, siltstone, fine sandstone, and marlstone are the dominant lithologies and represent a more distal, open lacustrine setting. Few marginal-lacustrine deposits are present in the San Felipe Hills, 


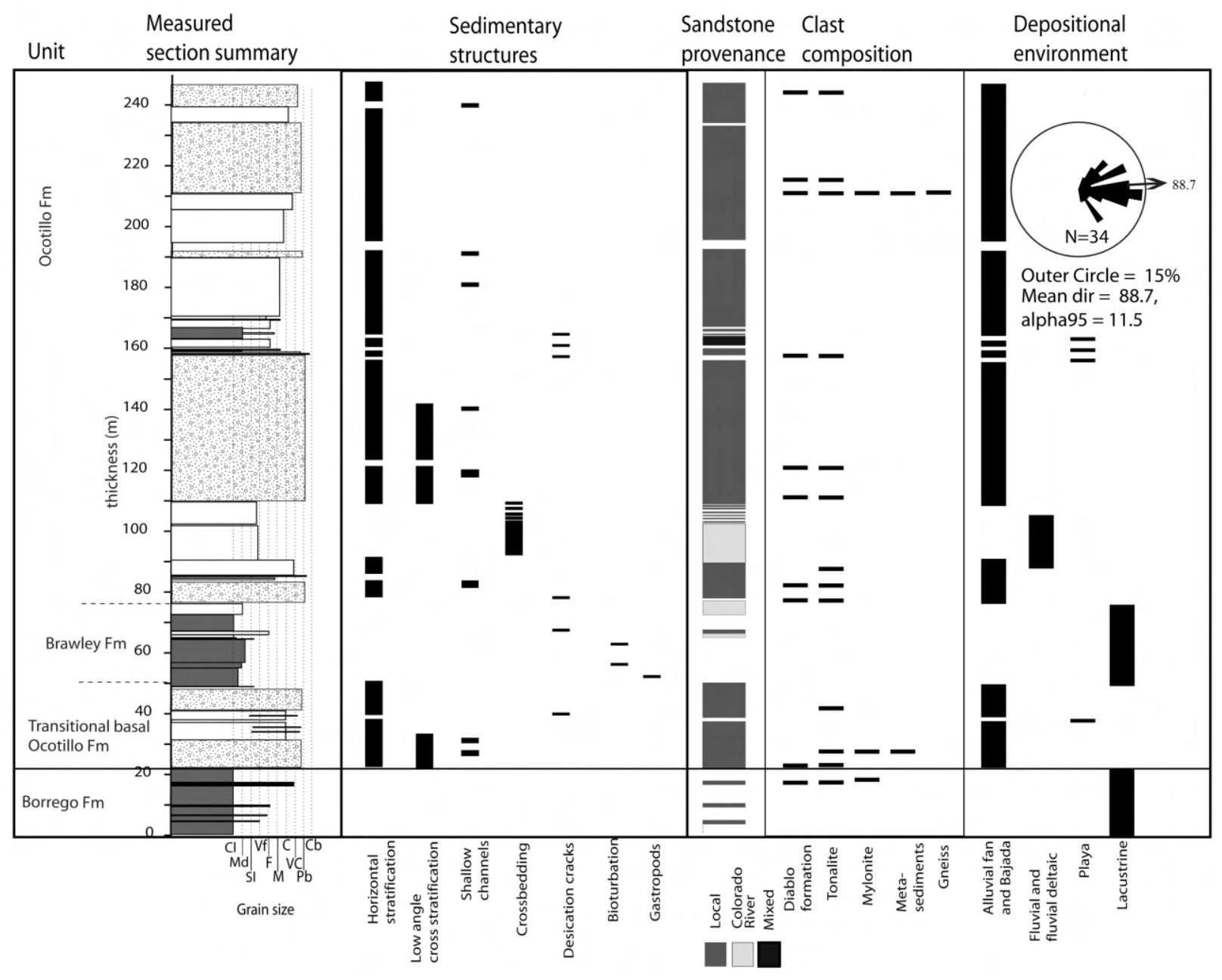

Figure 7. Measured section of the Ocotillo Formation in the Ocotillo Badlands. Major changes in facies, provenance, and sedimentary structures occur across the conformable contact, shown in black, separating the Ocotillo Formation from the underlying Borrego Formation. Grain sizes are as follows: Cl, claystone; $M d$, mudstone; S1, siltstone; $V f$, very fine-grain sandstone; $F$, fine-grain sandstone; $M$, medium-grain sandstone; $C$, coarse-grain sandstone; $V C$, very coarse-grain sandstone; $\mathrm{Pb}$, pebble conglomerate; $C b$, cobble conglomerate. Gray fill is siltstone or finer; pattern fill is pebble conglomerate or coarser. Location of section is shown as a star on figure 3. Paleoflow from clast imbrications. Mean direction $=88.7^{\circ}$.

and there is little physical evidence for desiccation of the Borrego lakebed.

Ocotillo Formation. Basal Contact. The base of the Ocotillo Formation is an angular unconformity in the western San Felipe Hills (fig. 8a), a disconformity in the east where the Ocotillo Formation interfingers with the Brawley Formation, and a sharp but conformable contact in the Ocotillo Badlands in the south (figs. 3, 6, 7). The contact appears to be conformable northwest of the San Felipe Hills and in the eastern Borrego Badlands (Bartholomew 1968, 1970; Lutz 2005; Lutz et al. 2006; J. R. Pettinga, unpublished map).

The angular unconformity beneath the Ocotillo
Formation is exposed principally in the western San Felipe Hills in a relatively narrow east-west belt on the south limb of the San Felipe anticline across an east-west distance of $15 \mathrm{~km}$ (fig. 3). These exposures persist from Tarantula Wash in the east to low hills just east of the Coyote Creek fault in the west. East of Tarantula Wash, the Ocotillo Formation disconformably overlies the Borrego Formation (fig. 3). In the Tarantula Wash area, the transition from angularity to a disconformity is expressed across a distance of 200-500 m (fig. 3). Clasts of marlstone from the underlying Borrego Formation are present locally in basal beds of the Ocotillo Formation above the disconformity in the 

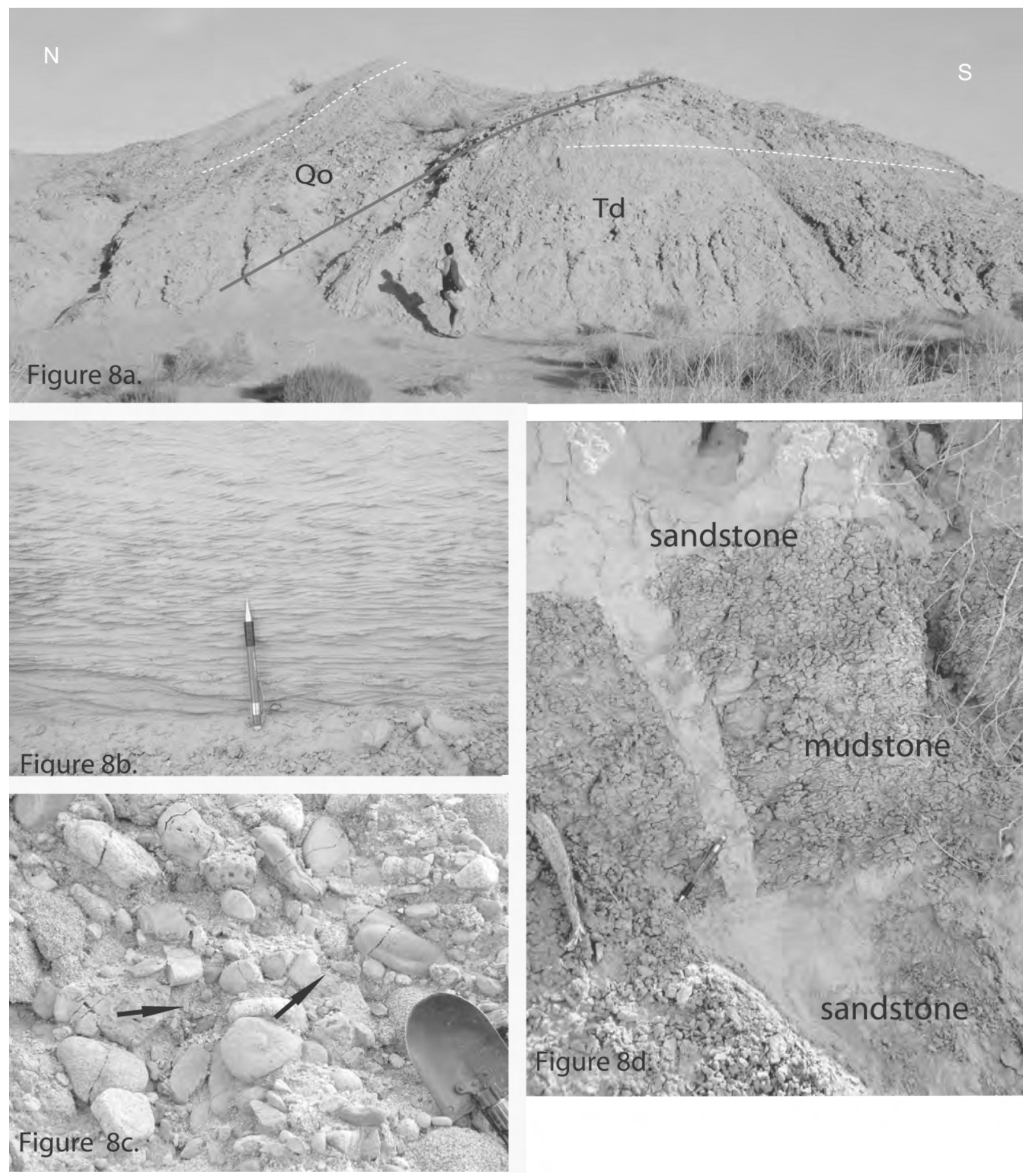

Figure 8. Photographs illustrating sedimentary structures in Pleistocene map units. $a$, Tilted angular unconformity in the southern San Felipe Hills between north-dipping Ocotillo Formation $(Q O)$ and south-dipping Diablo Formation $(T d)$ in Tarantula Wash on the south limb of the San Felipe anticline. $b$, Climbing ripples in the Brawley Formation. c, Conglomerate in Ocotillo Formation with numerous clasts of sandstone recycled from the Palm Spring Group (arrows). From $80 \mathrm{~m}$ in figure 7. $d$, Sand-filled desiccation cracks in mudstone of the Brawley Formation. 
eastern San Felipe Hills. Mapping shows the extent of the angular unconformity and its lateral change to a disconformity and a conformable contact to the north and south (fig. 3).

The north-south extent of the angular unconformity is less well constrained than the east-west extent. On the north limb of the San Felipe anticline, there is one outcrop where the Ocotillo Formation lies in angular unconformity on the Diablo Formation (near northwest corner of fig. 3). One kilometer north and west of this outcrop, the Ocotillo Formation disconformably overlies the transitional unit between the Diablo and Borrego formations (fig. 3). Near Seventeen Palms, $\sim 5 \mathrm{~km}$ farther north, the Ocotillo Formation overlies the Borrego Formation along an apparently conformable contact (Dibblee 1954, 1984; Bartholomew 1968, 1970; this study; J. Pettinga, unpublished map). On the south limb of the San Felipe anticline, the basal contact changes southward from an angular unconformity to a slight angular unconformity to a conformable contact within a stepover along the Coyote Creek fault in the Ocotillo Badlands (fig. 9). The angularity of the contact thus varies as a function of proximity to the San Felipe anticline except in the east, where a disconformable contact developed across a broad area east of the eastern tip of the San Felipe anticline and around the southeast tip of the Clark fault (fig. 3). The angular relationships north and south of the anticline define a progressive unconformity (e.g., Riba 1976).

Lithofacies. A well-exposed section of the Ocotillo Formation in the northern Ocotillo Badlands (fig. 7) contains roughly half of the $\sim 450 \mathrm{~m}$ of this unit that we estimate to be preserved based on map relationships. A detailed description of this section is in Kirby (2005). Field studies and mapping show that this section is typical of the Ocotillo Formation throughout the San Felipe Hills. Twenty-one kilometers to the east, the Oil Well Wash section contains just $16.5 \mathrm{~m}$ of distal Ocotillo Formation (pebbly sandstone) overlain by $480 \mathrm{~m}$ of Brawley Formation (fig. 6). Following the original definition of Dibblee (1954), we mapped deposits containing pebbly sandstone and conglomerate as Ocotillo Formation and finer-grained intervals without pebbly beds as Brawley Formation.

The Ocotillo Formation is characterized by conglomerate, pebbly to granular sandstone, sandstone, lesser siltstone and mudstone, and rare claystone (figs. 5-7). In the San Felipe Hills, moderately lithified pebbly arkosic sandstone is the dominant lithology, but medium-grained sandstone and mudstone are locally abundant components in the lower third of the Ocotillo Formation. Sedimentary structures include horizontal to low-angle stratification and a few shallow channel fills with imbricated clasts. Recycled clasts of sandstone from older Pli-

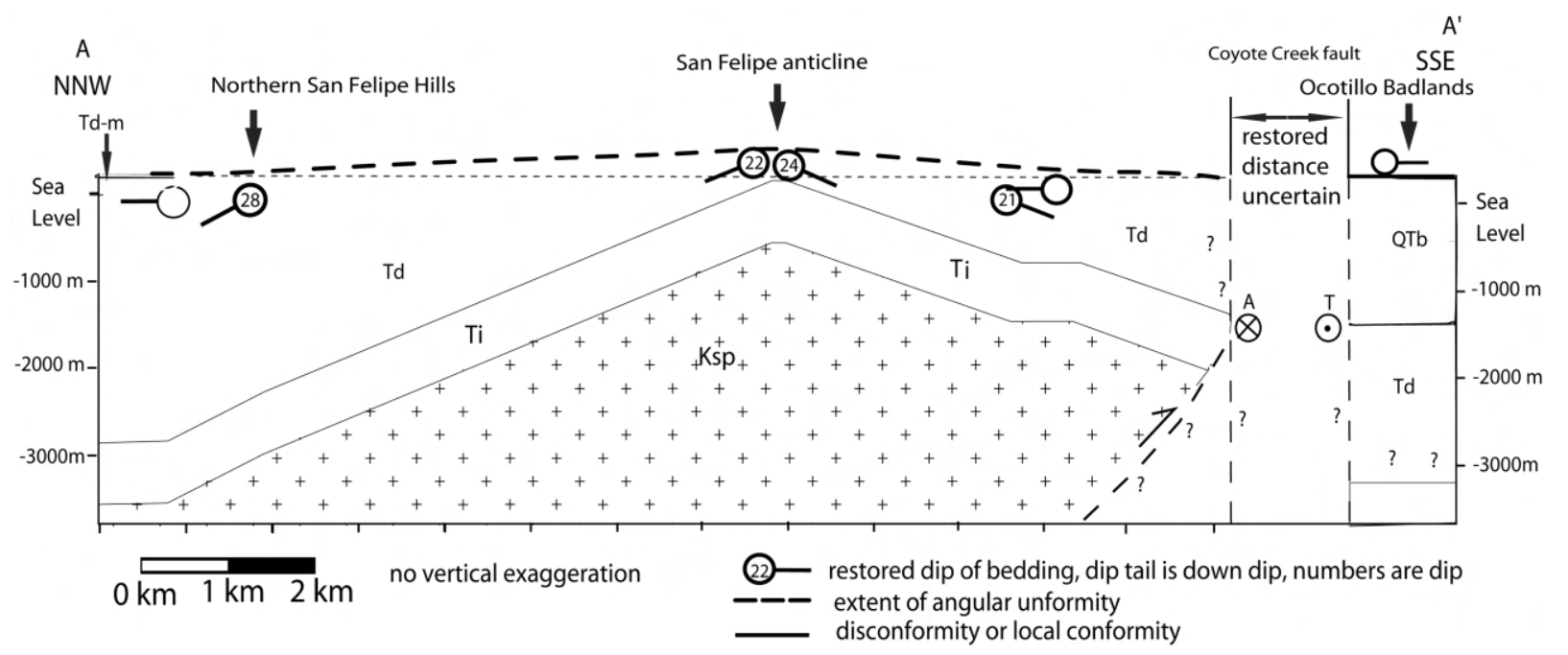

Figure 9. Reconstructed cross section of the San Felipe anticline in the western San Felipe Hills at $1 \mathrm{Ma}$, created from the angular relations between the Ocotillo Formation and older units beneath it. Offset across the Coyote Creek fault along the south limb of the San Felipe anticline is uncertain. Units correspond with those used in figures 3 and 4. Dip tadpoles without numbers indicate flat sub-Ocotillo Formation bedding. See figure 3 for location of cross section. Relict high at crest of San Felipe anticline is arbitrarily shown with $250 \mathrm{~m}$ of relief. 
ocene units (Diablo and perhaps Borrego formations) are common and far more abundant than shell-bearing recycled clasts of the latest Miocene to Pliocene Imperial Group.

In the measured section at Oil Well Wash, a thin $(16.5 \mathrm{~m})$ tongue of Ocotillo Formation separates the Brawley Formation from underlying Borrego Formation (figs. 3, 6). Basal beds of the Ocotillo Formation overlie a sharp disconformable contact and locally contain pebbles and rare cobbles of tonalite. The Ocotillo Formation consists of horizontally stratified, locally derived sandstone and pebbly sandstone that fines up-section and is overlain by massive mudstone of the lower Brawley Formation (at $145 \mathrm{~m}$ in the section; fig. 6).

Provenance and Paleocurrents. The composition of sand and granules in the Ocotillo Formation varies significantly, defining two distinct compositional modes. Most (90\%) sand-rich deposits contain subrounded granular to very coarse- to fine-grained quartz, plagioclase, and biotite (L-suite), which are clearly derived from nearby basement uplifts in the eastern Peninsular Ranges (fig. 7). Some intervals $(\sim 10 \%)$ are dominated by Colorado River-derived (Csuite) sand with some addition of L-suite sand. The C-suite sand is restricted to lacustrine and fluvialdeltaic intervals, e.g., between 50 and $100 \mathrm{~m}$ in the measured section in the Ocotillo Badlands (fig. 7).

The composition of pebble- to cobble-sized clasts is fairly uniform in the Ocotillo Formation. Clasts are dominantly tonalite, with fewer clasts of Csuite sandstone recycled from Pliocene units, metasedimentary schist and marble, mylonite, and gneiss (fig. 7). Clasts of C-suite sandstone reworked from the Pliocene formations are generally less common, although locally abundant, and are present throughout the unit. Directly above the base of the Ocotillo Formation in the Ocotillo Badlands, clasts include tonalite from the eastern Peninsular Ranges and up to $30 \%$ recycled sandstone from the Diablo Formation (figs. 7, 8c).

Clast imbrications were measured at six intervals in the Ocotillo Badlands. The tilt-corrected mean paleoflow direction is overall to the east based on 34 clast imbrications (fig. 7). These flow directions support derivation of the Ocotillo Formation from nearby basement uplifts west of the study area.

Depositional Environments. Based on the coarse grain size, poor to moderate sorting, and abundance of planar to low-angle cross-bedding, we infer that pebbly and granular sandstone of the Ocotillo Formation accumulated by sheet-flood deposition in medial to distal alluvial fans. Sandy and muddy facies are interpreted as fluvial and deltaic deposits (fig. 7). Evidence for lacustrine deposition is limited but is seen within a $77.5-\mathrm{m}$-thick transition in the lower Ocotillo Formation in the northern Ocotillo Badlands, where Borrego and Ocotillo lithofacies alternate (fig. 7). This interval, which is lithologically equivalent to the Brawley Formation farther east, contains laminated mudstone and claystone with lacustrine faunas, including gastropods. Fluvial to deltaic deposition is indicated by crossbedding and fining-up trends between 86 and 109 m (fig. 7).

Brawley Formation. Overview. The base of the Brawley Formation in the eastern San Felipe Hills is defined by the lowest trough cross-bedded, locally derived sandstone in erosional contact with underlying red claystone and mudstone of the Borrego Formation. The contact is sharp and commonly displays 1-2 $\mathrm{m}$ of erosional relief. Throughout most of the San Felipe Hills, the basal contact and overlying Brawley Formation have been extensively folded and faulted by postdepositional deformation (Dibble 1984; Heitman 2002; Lilly 2003; Kirby 2005; fig. 3). The Brawley Formation is internally conformable and lacks observable growth strata at map and outcrop scale.

We measured and described $480 \mathrm{~m}$ of Brawley Formation along Oil Well Wash, in the southeast part of the study area (figs. 3, 6). The section was compiled from three separate legs that were traced and/or correlated across postdepositional folds and faults using distinctive marker beds (fig. 6). Section legs 2 and 3 were correlated across the Extra fault zone using a prominent series of marl units and an overlying channel complex at 475 to $498 \mathrm{~m}$ in the section (fig. 6). Alternatively, this marker couplet may correlate with a marlstone-sandstone interval between 422 and $450 \mathrm{~m}$ in the section. This alternate correlation is not preferred because of a poor stratigraphic match above the marker couplet.

Sedimentary Lithofacies and Depositional Environment. The Brawley Formation at Oil Well Wash consists of three main lithofacies associations: (1) cross-bedded to planar-bedded sandstone with weakly developed calcic paleosols; (2) laminated and massive mudstone, claystone, and marlstone with 0.5 - to 1.5 -m-deep desiccation cracks, rare evaporite beds, and locally abundant microfossils; and (3) well-sorted sandstone with large-scale highangle cross-stratification. These facies are repeated many times.

Cross-bedded to planar-bedded sandstone. Sandstone-dominated portions of the Brawley Formation contain abundant channel-fill deposits that 
generally fine up from sandstone to siltstone and mudstone and typically occur in units $2-6 \mathrm{~m}$ wide and 1-4 m high (e.g., 425-450 m; figs. 6, A1D). Mudstone intraclasts are common and cobbles and armored mudballs are rare near the base of channelfill deposits. This facies contains abundant climbing ripple cross-lamination, trough crossbedding, and folded convolute laminations (fig. $8 b$ ). Several composite, vertically stacked channel-fill complexes up to $20 \mathrm{~m}$ thick were observed at Oil Well Wash. Some mudstone beds contain weak calcic paleosols and sand-filled desiccation cracks. We interpret this facies association to represent sandy channels that accumulated in a fluvial-deltaic environment.

Laminated to massive mudstone, claystone, and marlstone. Red to red-brown mudstone and claystone are commonly interbedded with sandstone in beds ranging from $<1 \mathrm{~m}$ to $3-4 \mathrm{~m}$ and are the dominant lithology in the upper $\sim 200 \mathrm{~m}$ of the measured section (fig. 6). These deposits are laminated to massive and show rare burrow mottling. Marlstone consists of silty to muddy micrite beds, typically $20-30 \mathrm{~cm}$ thick, that have abundant microfossils of foraminifers, ostracods, and gastropods (table A1). Marlstone is typically interbedded with claystone and mudstone and less commonly with erosional-based channel sandstone. Intervals of stacked thin marlstone beds are up to $2 \mathrm{~m}$ in thickness and make useful stratigraphic and structural markers. Locally derived sandstone is commonly associated with marlstone intervals. Sedimentary structures in marlstone include soft sediment deformation, bioturbation, and occasional crossstratification.

Very large sand-filled desiccation cracks are common in mudstone and claystone of the Brawley Formation. The cracks are well developed; many taper downward and are filled from above with locally derived sand (fig. 8d; fig. A1 $A, \mathrm{~A} 1 B$, available in the online edition or from the Journal of Geology office). Some sand-filled cracks contain faint subhorizontal laminations in the crack fill. The cracks are up to $1.5 \mathrm{~m}$ deep and $40 \mathrm{~cm}$ wide. When seen in plan view, the desiccation cracks are polygonal and up to 1-2 $\mathrm{m}$ across, but most polygons are $30-70$ $\mathrm{cm}$ across (fig. A1 $B$ ). Soil features in claystone and mudstone of the Brawley Formation are weakly developed and represented by small calcic rhizo concretions and irregular rounded calcic nodules up to $3 \mathrm{~cm}$ in length. We infer that this facies association was deposited in a nearshore lacustrine environment that experienced multiple cycles of flooding and drying.

Well-sorted sandstone with high-angle cross- bedding. Well-sorted sandstone at Oil Well Wash occurs in intervals of large-scale (3-4 m), high-angle cross-stratification interbedded with lenticular beds of massive to laminated mudstone and claystone (260-400 m; figs. 6, A1C). Cross-bedding in this facies is characterized by stacked sets of steep tabular foresets up to $10-15 \mathrm{~m}$ thick. Sandstone is extremely well sorted and contains thin segregated laminations of detrital biotite. We interpret this facies association to record eolian sand dunes that migrated across fluvial-deltaic deposits into nearshore parts of a lake that occupied the Salton Trough.

Micropaleontology. In situ microfossils in the Brawley Formation at Oil Well Wash are primarily freshwater forms (micromollusks, ostracods, chara, and plant fragments) but also include some brackish to saline forms (echinoids and foraminifers; fig. 6; table A1). Several samples contain reworked Cretaceous planktic foraminifers, consistent with recognition of C-suite sandstone reworked from the foram-bearing Pliocene Diablo Formation.

Provenance and Paleocurrents. Sandstone in the Brawley Formation at Oil Well Wash contains up to $\sim 60 \%$ locally derived (L-suite) sand rich in subrounded to angular plagioclase, quartz, and biotite (fig. 6). Colorado River-derived (C-suite) sand makes up $\sim 35 \%$ of sand documented in this area, and mixed-composition sand is minor $(\sim 5 \%)$. The L-suite and C-suite sandstone beds alternate on a $\sim 5 \mathrm{~m}$ scale with some mixing of the two petrofacies.

The Brawley Formation contains many welldeveloped paleocurrent indicators such as channel scours, foresets, ripples, and trough and planar cross-beds. Paleocurrent directions were measured primarily from channel axes, cross-bedding, and small-scale climbing-ripple lamination in the San Felipe Hills (figs. 6, 8b). The tilt-corrected mean of 51 measurements is $50^{\circ}$, or northeasterly (fig. 6). Paleocurrents are identical in the L-suite and Csuite petrofacies.

Depositional Environments. Two thirds of the Brawley Formation in Oil Well Wash consists of fluvial and fluvial-deltaic facies (cross-bedded to planar-bedded sandstone facies; fig. 6). Fluvial and fluvial-deltaic facies dominate the section from 156 $\mathrm{m}$ to $450 \mathrm{~m}$ and include thin intervals of lacustrine and eolian facies. Eolian sandstone interbedded with fluvial and deltaic deposits records intermittent eastward migration of sand dunes up to $4 \mathrm{~m}$ high (fig. A3c). Calcic paleosols, well-developed 
large desiccation cracks, at least one 50-cm-thick gypsum bed, and significant sections of eolian sandstone all reflect semiarid to arid conditions during deposition of the Brawley Formation (e.g., Plummer and Gostin 1981; Wright 1986; Weinberger 2001). The intervals that show the most evidence for extended subaerial exposure and soil formation also contain eolian deposits (fig. 6).

Lacustrine deposits comprise $20 \%$ of the Brawley Formation at Oil Well Wash (fig. 6). The most diagnostic lithofacies in the lacustrine association are fossiliferous marlstone, claystone, and mudstone with lacustrine microfaunas. Flooded conditions alternated about 30 times with subaerial exposure, producing the well-developed sand-filled desiccation cracks (figs. 6, 8d). These fluctuations probably resulted from episodic filling and drying of the ancient Salton Sea by distributaries of the Colorado River, similar to the behavior of the Salton Sea in Holocene time (Waters 1983). Two intervals containing marginal-marine microfossils indicate that lake waters were occasionally brackish and possibly connected with the Gulf of California to the south. Introduction of marine faunas may have occurred during episodic connection of the Pleistocene lake to the Gulf of California.

Magnetostratigraphy. Fourteen of 16 paleomagnetic sampling sites along Oil Well Wash in the upper Borrego and Brawley formations preserve a stable primary magnetization (figs. 6, A1). We collected four to seven samples per site at sites spaced approximately $40 \mathrm{~m}$ apart in the measured section. Paleomagnetic methods are described in a companion article (Lutz et al. 2006). Polarity reversals documented in the Oil Well Wash section were correlated to the magnetic polarity timescale of Cande and Kent (1995) to assign absolute ages. We compared our data with the upper $2 \mathrm{~m}$.yr. of the polarity timescale because the correlative Ocotillo Formation in the Borrego Badlands contains Irvingtonian vertebrate fossils $(<1.5 \mathrm{Ma})$ and the 0.76-Ma Bishop ash (Remeika and Beske-Diehl 1996; Lutz 2005; Lutz et al. 2006).

Three reversals are present in the Oil Well Wash section (figs. 6, A2). The lowest reversal coincides closely with the disconformity at the base of the Ocotillo Formation (fig. 6). We correlate this reversal to the base of the Jaramillo subchron (1.070 $\mathrm{Ma})$. If we assume that this reversal lies halfway between the control sample sites, the base of the Jaramillo subchron would be placed at $135 \pm 30 \mathrm{~m}$. We instead choose to place the base of the Jaramillo subchron at the basal Ocotillo disconformity, because this reversal coincides with the base of the
Ocotillo Formation at two other locations in the Borrego and Ocotillo Badlands (Brown et al. 1991; Lutz 2005; Lutz et al. 2006; figs. 3, 6). The coincidence of this reversal with a major lithologic change across this contact is best explained if the base of the Ocotillo Formation records nearly synchronous basin-wide gravel progradation at $\sim 1.1$ $\mathrm{Ma}$ across the entire San Felipe-Borrego basin.

The upper two paleomagnetic reversals were placed at the midpoints between sample sites with opposite polarity, and the uncertainty in stratigraphic position of these reversals is equal to the thickness from the midpoint to the bounding sample locations. The top of the Jaramillo normal subchron $(0.990 \mathrm{Ma}$ ) is thus placed at $274 \pm 36 \mathrm{~m}$ (fig. 6). The base of the Brunhes normal is placed at $480 \pm 2 \mathrm{~m}$, between 03Qb24 and 03Qb21, based on combined stratigraphic and paleomagnetic correlation of section leg 3 to section leg 2 (fig. 6). If section leg 3 is not correlated into leg 2 , the reversal would be interpreted to lie at $448 \pm 34 \mathrm{~m}$, halfway between 03Qb25 and 03Qb24.

We calculate sedimentation rates using both the preferred and alternate positions of the upper reversal within the approximately $550 \mathrm{~m}$ of section (in the data depository). This analysis shows that the Brawley Formation has a time-averaged sediment accumulation rate between $1.2 \pm 0.1$ and $1.1 \pm 0.2 \mathrm{~mm} / \mathrm{yr}$, with deposition slowing upsection from $1.7-1.8 \mathrm{~mm} / \mathrm{yr}$ to $0.8-1.1 \mathrm{~mm} / \mathrm{yr}$. The top of the Brawley Formation (i.e., end of deposition in this area) is estimated at about 0.6 to $0.5 \mathrm{Ma}$. Lateral correlation of the Ocotillo and Brawley formations means that both are $\sim 1.1 \mathrm{Ma}$ or younger at their base and 0.5-0.6 $\mathrm{Ma}$ at the top. We infer that the basal Ocotillo Formation is probably somewhat younger than this where it laps across the crest of the San Felipe anticline (below), because growth of the anticline probably produced a period of nondeposition during latest Borrego to early Ocotillo time.

San Felipe Anticline. Structural, gravity, and magnetic data define a large east-west trending anticline in the western half of the map area (Dibblee 1954, 1984; Reitz 1977; Heitman 2002; this study; figs. 3, A3). The San Felipe anticline formed in Pleistocene time and is a structure that persists from at least Squaw Peak in the west to the central San Felipe Hills in the east $(\sim 15 \mathrm{~km})$. Angular relations beneath the sub-Ocotillo unconformity in the western San Felipe Hills show that most of the San Felipe anticline formed before the overlying part of the Ocotillo Formation was deposited across it, as originally suggested by Dibblee $(1954,1984)$. 
The progressive unconformity indicates that the San Felipe anticline folded the Borrego and Diablo formations and Imperial Group before or during deposition of the Ocotillo Formation across its crest.

A 30-mGal gravity high coincides closely with the San Felipe anticline as mapped at the surface (fig. A3) and defines the subsurface extent of the basement-cored part of the anticline. The anticline appears to end or be truncated $1-2 \mathrm{~km}$ east of the Powerline fault, a strand of the Clark fault in the central San Felipe Hills (fig. 3). To the west, the fold may terminate at the Coyote Creek fault, or more likely, persist west another $9 \mathrm{~km}$.

The dipping limbs of the anticline extended roughly $10 \mathrm{~km}$ from north to south and $15 \mathrm{~km}$ from the Coyote Creek fault to the eastern tip of the fold. The paleoanticline probably extended west to Borrego Mountain to the southwest side of the Coyote Creek fault for a total east-west length of 24 $\mathrm{km}$ based on the continuation of the gravity high (fig. A3) and thickness patterns in the Borrego Badlands (Lutz et al. 2006). Relationships in the Borrego Badlands indicate tilting of the north limb of the San Felipe anticline during deposition of the Ocotillo Formation. Younger, closely spaced eastwest trending folds and east-west striking faults deform both the Ocotillo Formation and underlying units but do not tighten the anticline significantly (Kirby 2005).

The angular relationships beneath the Ocotillo Formation in the western San Felipe Hills and south of Squaw Peak were used to produce a reconstructed cross section (A-A' on fig. 3 ) of the paleo-San Felipe anticline at the time of initial deposition of the Ocotillo and Brawley formations (fig. 9). The cross section restores post-Ocotillo north-south shortening but does not restore slip on strike-slip faults with uncertain offset. The restored cross section shows that the Diablo Formation dipped $28^{\circ}$ on the north limb and $16^{\circ}-24^{\circ}$ on the south limb of the anticline before deposition of the Ocotillo Formation (fig. 9). The exact dimensions of the south limb are poorly constrained because exposures of the conformable Ocotillo-Borrego contact in the Ocotillo Badlands are located between two major strands of the Coyote Creek fault (figs. 3,91 , which together have between 1.5 and $4 \mathrm{~km}$ of right slip (Janecke et al. 2005a; Steely 2006).

\section{Interpretation of Stratigraphic Relationships}

1.1-Ma Change in Depositional Environment and Provenance. The Brawley and Ocotillo formations are distinct units that record a very different provenance and tectonic setting than the underlying
Borrego Formation. The Borrego Formation consists mostly of mudstone and claystone that accumulated under persistent open lacustrine conditions and preserves little evidence for subaerial exposure. In contrast, the Brawley Formation is sandier, more variable in its lithofacies and environments, has a widespread disconformity at its base, and preserves abundant evidence for subaerial exposure on the margin of an arid lake. Coarse alluvial deposits of the laterally equivalent Ocotillo Formation show an even more pronounced contrast with lacustrine fines of the Borrego Formation. The Borrego Formation accumulated in a large lacustrine depocenter within the San Felipe-Borrego basin, whereas the Brawley and Ocotillo formations record an abrupt shift of the shoreline tens of kilometers eastward to near the shore of the modern Salton Sea.

The source of sediment in the Brawley Formation differs significantly from that of the older Borrego and Diablo formations. The Borrego and Diablo formations in the San Felipe Hills are dominated by sand and mud of the Colorado River $(>90 \%)$ and are clearly first-cycle deposits (Winker 1987; Guthrie 1990; Winker and Kidwell 1996). In contrast, the Brawley and Ocotillo formations are derived mainly from basement rocks exposed in local uplifts, but they also contain some sand and sandstone recycled from older, uplifted basin fill. Sandstone clasts eroded from the Diablo Formation, which appear just above the base of the Ocotillo and Brawley formations, indicate that sediment recycling began during initial progradation at $\sim 1.1$ $\mathrm{Ma}$. We infer that much of the C-suite sand in these two formations was recycled from older basin-fill deposits (figs. 6, 7).

Stratigraphic Nomenclature. The many differences between the Brawley and Borrego formations suggest that the name Borrego Formation should be reserved for older Pliocene and early Pleistocene lacustrine deposits that lack evidence for repeated cycles of desiccation and flooding. Middle and Late Pleistocene deposits east of the Salton Sea have been mapped as and named Borrego Formation but are more closely related to the Brawley Formation because they contain evaporites, sand-filled desiccation cracks, and other evidence for drying episodes (Babcock 1974; Herzig et al. 1988). Our proposed change in nomenclature would highlight the differences between Pliocene to early Pleistocene perennial lake beds (Borrego Formation) and the post $\sim 1$ Ma playa-like lacustrine and deltaic deposits (Brawley Formation).

Paleogeography at 1 Ma. Based on our analysis, we produced a paleogeographic reconstruction of 
the southwestern Salton Trough during deposition of the Ocotillo and Brawley formations. It shows the overall east- to northeast-directed transport and lateral fining from medial to distal alluvial fans in the southwest, to fluvial-deltaic and lacustrine environments in the northeast near the modern Salton Sea (fig. 10). The large, east-trending San Felipe anticline partitioned the San Felipe-Borrego basin into smaller subbasins. The fluvial-deltaic system exposed in Oil Well Wash was located southeast of the east tip of the San Felipe anticline and was fed by a stream system that probably flowed along the synclinal axis south of the anticline (fig. 10). We infer that oblique dextral slip in the San Felipe fault zone along the front of the Vallecito and Fish Creek mountains, southwest of the study area, uplifted the older basinal rocks and underlying crystalline units that supplied voluminous L-suite and C-suite sediment to the Ocotillo and Brawley formations.

Several data sets support this interpretation. Paleoflow in the Ocotillo and Brawley formations was toward the east and northeast, and the mouth of the Colorado River was located far to the southeast during Brawley deposition (e.g., Winker and Kidwell 1986). Paleoflow measured in channels filled with L-suite and C-suite sand are indistinguishable and eastward. This makes it highly unlikely that the east-flowing fluvial-deltaic C-suite sediment was transported directly into the San Felipe Hills area from the Colorado River. Recycled clasts of sandstone occur in proximal Ocotillo Formation along the northeast margin of the Fish Creek Mountains, as expected if the source area was immediately to the southwest in the Vallecito and Fish Creek mountains (Steely 2006). This suggests that some of the C-suite sand in the Brawley Formation was stripped from an emergent terrane to the southwest. The crest of the intrabasinal San Felipe anticline may have also contributed C-suite sand and sandstone (fig. 10).

Tectonic Origin of 1.1-Ma Unconformities. Late Cenozoic gravel progradation and abrupt stratigraphic changes are sometimes driven by climate change (e.g., Smith 1994; Molnar 2004). We emphasize that tectonic processes were required to produce the angular unconformities, recycled clasts from previously buried basinal deposits, new faults, and basement uplifts, and to partition the formerly contiguous sedimentary basin above the West Salton detachment fault into two separate subbasins. Our interpretation is supported by the progressive to angular unconformity across the crest of the San Felipe anticline and near the San Felipe fault, southwestward coarsening and thickening of conglomeratic sediment toward the steep basin-bound-

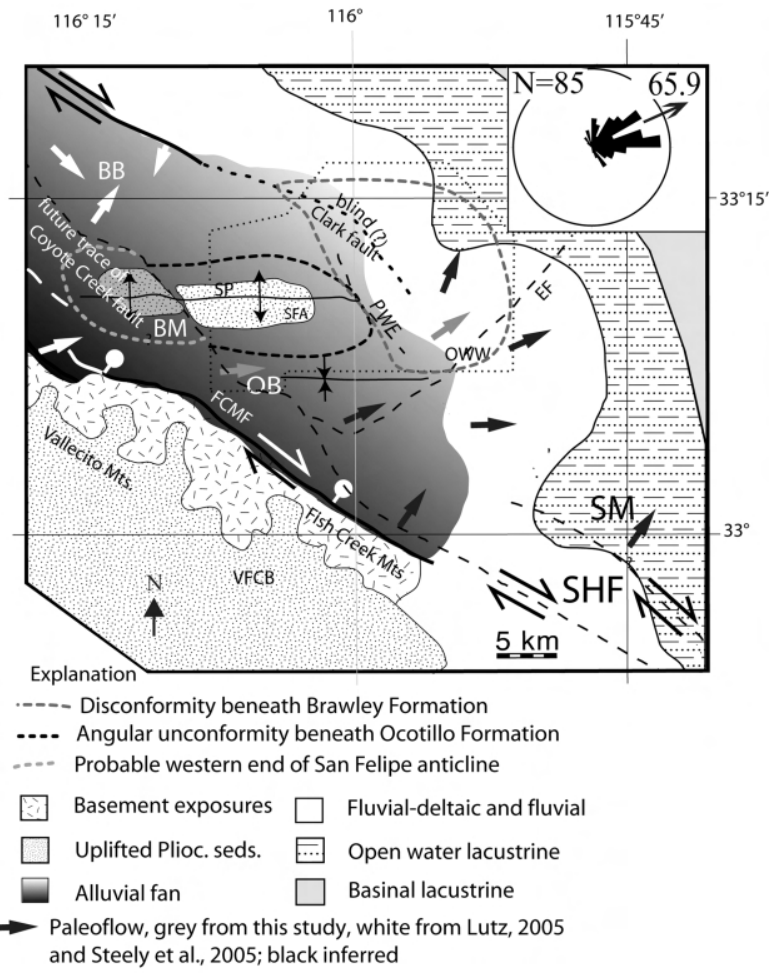

Figure 10. Paleogeography of the San Felipe Hills during deposition of the Ocotillo and Brawley formations just after $1 \mathrm{Ma}$. SFA, San Felipe anticline; $B B$, Borrego badlands; $E F$, Extra fault; $O B$, Ocotillo badlands; $O W W$, Oil Well Wash; SP, Squaw Peak; FCMF, Fish Creek Mountain fault; $V F C B$, Vallecito-Fish Creek subbasin; $B M$, Borrego Mountain; PWF, Powerline fault; $S M$, Superstition Mountains; SHF, Superstition Hills fault. Black dotted outline is the extent of the study area. In rose diagram: $\alpha_{95}=9.2$, outer circle $=15 \%$.

ing Fish Creek Mountain and Sunset faults, and the sudden new input and rapid progradation of coarse alluvial sediment derived from previously submerged basement blocks (this study; Steely et al. 2005; Steely 2006; fig. 10).

\section{Discussion of Tectonic Implications}

Tectonic Significance of the Paleo-San Felipe Anticline. The orientation and scale of the San Felipe anticline are consistent with wrench deformation produced by northwest-striking dextral strike-slip faults and a north-south trending maximum horizontal stress. The fold may still be growing slowly in the current dextral strain field, and this could explain prominent reentrants in the shoreline of Holocene Lake Cahuilla north and south of its axis. It is difficult to identify the specific faults or set 
of faults that produced the San Felipe anticline in early Pleistocene time. The San Felipe anticline connects the southeast tip of the Clark fault zone and the Extra fault with three dextral faults at its western end (the Fish Creek Mountains, Sunset, and the concealed Veggie line faults), so the fold seems to be related to young strike-slip faults. We rule out the West Salton detachment fault as the controlling structure because the detachment produced northwest- (not east-west) trending anticlines, and most of the detachment was inactive by this time (Steely et al. 2005; Steely 2006). All the data suggest that the San Felipe anticline is the complex result of wrench deformation between the emerging San Felipe and San Jacinto fault zones.

Sediments deposited above progressive unconformities typically become progressively younger onto the crest of the controlling high (e.g., Riba 1976). For this reason, dating of the laterally equivalent conformity or disconformity adjacent to the San Felipe anticline also dates initial deformation across the San Felipe anticline. We conclude that initial fold growth took place during early Ocotillo time, starting at $\sim 1.1 \mathrm{Ma}$. An alternative interpretation, that the San Felipe anticline formed during deposition of the upper Borrego Formation, before 1.1 Ma, and the disconformity beneath the Brawley Formation, reflects deposition after the end of anticlinal shortening, seems much less likely because it predicts unconformities and growth relationships within the upper Borrego Formation that were not observed during our reconnaissance mapping in that unit. Such an interpretation is inconsistent with northward thickening in the Ocotillo Formation in the Borrego Badlands and the subcrop of the younger Fonts Point Sandstone (Lutz et al. 2006).

Initiation of the San Felipe and San Jacinto Fault Zones. Our study in the San Felipe Hills provides strong stratigraphic and structural evidence for development of the San Felipe anticline and creation of topographic relief across the Fish Creek and Vallecito mountains due to initiation of the rightlateral San Felipe fault zone at approximately 1.1 Ma. A companion study (Steely 2006) suggests that the Sunset fault within the San Felipe fault zone may have initiated as a blind fault slightly earlier and propagated to the surface at about $1.1 \pm 0.2 \mathrm{Ma}$.

Our data are less clear about the initiation of the Coyote Creek and Clark strands of the San Jacinto fault zone in the San Felipe Hills area. The disconformable contact between the Borrego Formation and overlying Ocotillo and Brawley formations in the eastern San Felipe Hills roughly coincides with the lateral edge of widely distributed faults and folds of the southeast Clark fault zone. This relationship could reflect early uplift-perhaps at the crest of a broad, flat-topped box anticline with a northwest trend-above a nascent Clark fault that was still confined to the underlying basement. Similar geometries develop above blind strike-slip faults in sandbox experiments (Richard et al. 1989). If so, the deep basement portions of the Clark fault in the San Felipe Hills dates back to roughly 1.1 Ma. Alternatively, the disconformable contact may have developed across an unusually broad area east of the eastern tip of the San Felipe anticline and might be unrelated to the Clark fault (fig. 3). This interpretation seems less likely because it would requires the area east of the tip of the San Felipe anticline to have an unconformity with a greater lateral extent than the unconformity associated with the crest of the anticline. We also prefer the first interpretation because Lutz et al. (2006) showed that the Clark fault had formed and propagated to the surface by $1.0 \mathrm{Ma}$ a short distance northwest of our study area, near the Santa Rosa Mountains. Either model must explain the renewed subsidence that followed creation of the disconformity in the eastern San Felipe Hills and the subsequent rapid deposition of $\sim 550 \mathrm{~m}$ of Brawley Formation across a blind or future Clark fault zone.

It appears that many of the large dextral faults southwest of the San Andreas fault (San Jacinto, San Felipe, and the southeast Elsinore faults) initiated and propagated to the surface at roughly the same time in the early Pleistocene (Morton and Matti 1993; Matti and Morton 1993; Magistrale and Rockwell 1996; Janecke et al. 2005b; Steely 2006; this study; Lutz et al. 2006). Small and local differences in age of the oldest deformation at the surface of a few hundred thousand years could reflect the blind or hidden nature of these dextral fault zones during their initiation in the Salton basin or might be due to rapid lateral growth of their tips.

Based on the absence of local growth strata across closely spaced fold axes in the study area (fig. 3), we conclude that the current configuration of the San Jacinto fault zone in the Borrego Badlands and San Felipe Hills, with its many localized faults and folds, developed after the end of deposition of the Brawley and Ocotillo formations at $\sim 0.5-0.6 \mathrm{Ma}$ (Kirby 2005; Lutz et al. 2006). Uplift halted deposition, and small interconnected strike-slip faults of the Clark strand of the San Jacinto fault zone propagated to the surface in the San Felipe Hills and transferred deformation to the northeast-striking left-lateral Extra fault (Dibblee 1984; Kirby 
2005; fig. 3). We interpret this second change in dextral fault kinematics as an adjustment along existing faults. The San Felipe fault zone and Coyote Creek fault also became more transpressive at 0.5-0.6 Ma (Steely 2006; Lutz et al. 2006).

Regional Relationships. The Pleistocene unconformities in the San Felipe Hills, across the crest of the San Felipe anticline, and near the Fish Creek Mountains fault in the San Felipe-Borrego subbasin appear to record a major tectonic event along the Pacific-North American plate boundary in southern California. A similar angular unconformity across the crest of a large northwest-trending anticline in the Mecca Hills, parallel to the San Andreas fault, may date from the same time but probably records more missing time, because the entire Jaramillo event is missing there (Boley et al. 1994; Sheridan et al. 1994). Angular unconformities in the Indio Hills may also date to $\sim 1 \mathrm{Ma}$, and also omit the entire Jaramillo subchron (Boley et al. 1994).

At about $0.9 \mathrm{Ma}$, the Fish Creek-Vallecito subbasin (fig. 2) ended a $\sim 7$ m.yr. period of steady subsidence and began to be exhumed (Johnson et al. 1983; Dorsey et al. 2006). If further work confirms the similar geometry and age of these unconformities near the San Felipe, San Jacinto, Elsinore, and San Andreas fault zones, they probably reflect the abrupt and nearly synchronous inception of several strike-slip faults southwest of the southern San Andreas fault. We speculate that this regionwide southwestward shift in plate motion and creation of new dextral faults may have been caused by delamination or thinning of the upper mantle and/or lower crust beneath the eastern Peninsular Ranges (e.g., Mueller et al. 2006) and/or by changes and barriers to slip along the big bend of the San Andreas fault zone (e.g., Matti and Morton 1993; Morton and Matti 1993).

\section{Conclusions}

Claystone, mudstone, and minor sandstone of the Pliocene-Pleistocene Borrego Formation in the San Felipe Hills accumulated in a large, long-lived perennial lake across future traces of the San Jacinto fault zone. Depositional systems changed dramatically $\sim 1.1 \mathrm{Ma}$ as the pebbly and sandy Ocotillo and Brawley formations prograded synchronously across the large $(\sim 30 \mathrm{~km} \times 60 \mathrm{~km})$ San Felipe-Bor- rego subbasin in response to initiation of the San Felipe oblique-dextral fault. Coarse detritus was shed from a new intrabasinal fault block uplifted southwest of the San Felipe fault zone. The large transpressional San Felipe anticline formed at roughly the same time.

The Clark fault of the San Jacinto fault zone propagated to the surface 1.0 Ma near the Santa Rosa Mountains (Lutz et al. 2006) and probably produced a widespread disconformity in the San Felipe Hills beneath the Brawley Formation at $\sim 1.1 \mathrm{Ma}$. Initiation of the San Felipe and San Jacinto fault zones in early Pleistocene time deactivated the West Salton detachment fault and subdivided its supradetachment basin into the rapidly subsiding San Felipe-Borrego subbasin in the north and the slowly subsiding Vallecito-Fish Creek subbasin in the south (Johnson et al. 1983; Steely 2006).

Most of the north-south shortening in the San Felipe Hills postdates deposition of the Ocotillo and Brawley formations and indicates that the modern, more contractional geometry of the southeastern San Jacinto fault system was established at $\sim 0.6-0.5 \mathrm{Ma}$. Altogether, our work in the San Felipe-Borrego basin (Kirby 2005; Steely 2006; Lutz et al. 2006) and prior studies in the Mecca and Indio Hills and Fish Creek-Vallecito basin record creation of several new dextral faults along the plate boundary in the early Pleistocene. The San Andreas fault system became more complex about $1.1 \mathrm{Ma}$ and broadened to the southwest.

\section{A C K N O W L E D G M E N T S}

Thanks to R. Crippen, R. Blom, and T. Rockwell for Landsat and SPOT data of the area. G. Girty provided his mapping before publication in the south-central hills. This research was supported by grants from the National Science Foundation (to $S$. U. Janecke, R. J. Dorsey, and B. A. Housen) and Petroleum Research Fund of the American Chemical Society (S. U. Janecke). J. Matti provided additional aerial photographs. G. Jefferson and the staff of the Anza-Borrego Desert State Park kindly housed our field crews. This research benefited from insightful discussions with P. Cobbold, J. Evans, G. Girty, G. Jefferson, A. Lutz, G. Retallack, T. Rockwell, and R. Weldon. Thorough reviews by J. Matti, B. Powell, J. Evans, and A. Anderson improved the final version of the article. 


\section{R E F E R E N C E S C I T E D}

Atwater, T. 1970. Implications of plate tectonics for the Cenozoic tectonic evolution of western North America. Geol. Soc. Am. Bull. 81:3513-3536.

Axen, G. J., and Fletcher, J. M. 1998. Late MiocenePleistocene extensional faulting, northern Gulf of California, Mexico and Salton Trough, California. Int. Geol. Rev. 40:217-244.

Babcock, E. A. 1974. Geology of the northeast margin of the Salton Trough, Salton Sea, California. Geol. Soc. Am. Bull. 85:321-332.

Bartholomew, M. J. 1968. Geology of the southern portion of the Fonts Point quadrangle and the southwestern portion of the Seventeen Palms quadrangle, San Diego County, California. MS thesis, University of Southern California, Los Angeles.

- 1970. San Jacinto fault zone in the Imperial Valley, California. Geol. Soc. Am. Bull. 81:3161-3166.

Boley, J. L.; Stimac, J. P.; Weldon, R.; and Rymer, M. J. 1994. Stratigraphy and paleomagnetism of the Mecca and Indio hills. In McGill, S. F., and Ross, T. M., eds. Geological investigations of an active margin. Geological Society of America, Cordilleran Section guidebook. Redlands, CA, San Bernardino County Museum, p. 336-344.

Brown, N. N.; Fuller, M. D.; and Sibson, R. H. 1991. Paleomagnetism of the Ocotillo Badlands, southern California, and implications for slip transfer through an antidilational fault jog. Earth Planet. Sci. Lett. 102: 277-288.

Cande, S. C., and Kent, D. V. 1995. Revised calibration of the geomagnetic polarity timescale for the Late Cretaceous and Cenozoic. J. Geophys. Res. 100:60936095.

Dibblee, T. W., Jr. 1954. Geology of the Imperial Valley region, California. In Jahns, R. H., ed. Geology of southern California. Calif. Div. Mines Bull. 170:2128.

-1984. Stratigraphy and tectonics of the San Felipe Hills, Borrego Badlands, Superstition Hills and vicinity. In Rigsby, C. A., ed. The Imperial Basin: tectonics, sedimentation and thermal aspects. SEPM (Soc. Econ. Paleontol. Mineral.) Field Trip Guideb. 40:31-44.

Dorsey, R. J. 2002. Stratigraphic record of Pleistocene initiation and slip on the Coyote Creek fault, lower Coyote Creek, southern California. In Barth, A., ed. Contributions to crustal evolution of the southwestern United States. Geol. Soc. Am. Spec. Pap. 365:251269.

Dorsey, R. J.; Fluette, A.; McDougall, K. A.; Housen, B. A.; Janecke, S. U.; Axen, G. A.; and Shirvell, C. R. 2006. Chronology of Miocene-Pliocene deposits at Split Mountain Gorge, southern California: a record of regional tectonics and Colorado River evolution. Geology, forthcoming.

Dorsey, R. J., and Janecke, S. U. 2002. Late Miocene to Pleistocene West Salton detachment fault and basin evolution, southern California: new insights. Geol. Soc. Am. Abstr. Program 34:248.

Dorsey, R. J.; Janecke, S. U.; Kirby, S.; Axen, G.; and Steely, A. N. 2004. Pliocene lacustrine transgression in the Western Salton Trough, southern California: implications for regional tectonics and evolution of the Colorado River delta. Geol. Soc. Am. Abstr. Program 36:317.

Dronyk, M. P. 1977. Stratigraphy, structure and a seismic refraction survey of a portion of the San Felipe Hills, Imperial Valley, California. MS thesis, University of California, Riverside.

Feragen, E. S. 1986. Geology of the southeastern San Felipe Hills, Imperial Valley, California. MS thesis, San Diego State University, San Diego, CA.

Fialko, Y. 2006. Interseismic strain accumulation and the earthquake potential on the southern San Andreas fault system. Nature 441:968-971.

Frost, E. G.; Fattahipour, M. J.; and Robinson, K. L. 1996. Emerging perspectives on the Salton Trough region with an emphasis on extensional faulting and its implications for later San Andreas deformation. In Abbott, P. L., and Seymour, D. C., eds. Sturzstroms and detachment faults, Anza-Borrego Desert State Park, California. South Coast Geological Society annual field trip guide book, no. 24. Santa Ana, CA, South Coast Geological Society, p. 81-122.

Guthrie, L. L. 1990. An internally standardized study of the Cenozoic sand and sandstone compositions, Salton basin, southern California: implications for the rift basin evolution with emphasis on the Palm Spring and Imperial formations. MS thesis, San Diego State University, San Diego, CA.

Haq, B. U.; Hardenbol, J.; and Vail, P. R. 1987. Chronology of fluctuating sea levels since the Triassic. Science 235:1156-1157.

Heitman, E. A. 2002. Characteristics of the structural fabric developed at the termination of a major wrench fault. MS thesis, San Diego State University, San Diego, CA.

Herzig, C. T.; Mehegan, J. M.; and Stelting, C. E. 1988. Lithostratigraphy of the State 2-14 Borehole; Salton Sea Scientific Drilling Project. J. Geophys. Res. 93: 12,969-12,980.

Janecke, S. U.; Kirby, S. M.; Langenheim, V. E.; Housen, B.; Dorsey, R. J.; Crippen, R. E.; and Blom, R. G. 2004. Kinematics and evolution of the San Jacinto fault zone in the Salton Trough: progress report from the San Felipe Hills area. Geol. Soc. Am. Abstr. Program 36: 37.

Janecke, S. U.; Kirby, S. M.; Langenheim, V. E.; Steely, A. N.; Dorsey, R. J.; Housen, B., and Lutz, A. $2005 a$. High geologic slip rates on the San Jacinto fault zone in the SW Salton Trough, and possible near-surface slip deficit in sedimentary basins. Geol. Soc. Am. Abstr. Program 37:275. 
Janecke, S. U.; Kirby, S. M.; Steely, A. N.; Lutz, A.; Dorsey, R. J.; Housen, B.; and Langenheim, V. E. 2005 b. Early Pleistocene emergence of new dextral faults southwest of the southern San Andreas fault, Salton Trough. Abstracts for the annual meeting of the Southern California Earthquake Center (SCEC), Palm Springs, September 2005, p. 41. http://www.scec.org/ meetings/2005am/2005abstracts.doc.

Johnson, N. M.; Officer, C. B.; Opdyke, N. D.; Woodard, G. D.; Zeitler, P. K.; and Lindsay, E. H. 1983. Rates of late Cenozoic tectonism in the Vallecito-Fish Creek basin, western Imperial Valley, California. Geology 11:664-667.

Kairouz, M. 2005. Geology of the Whale Peak region of the Vallecito Mountains: emphasis on the kinematics and timing of the West Salton detachment fault, southern California. MS thesis, University of California, Los Angeles.

Kirby, S. M. 2005. Quaternary tectonic and structural evolution of the San Felipe Hills, California. MS thesis, Utah State University, Logan, scale, $1: 48,000$.

Kirby, S. M.; Janecke, S. U.; Dorsey, R. J.; Housen, B. A.; and McDougall, K. 2004. A 1.07 Ma change from persistent lakes to intermittent flooding and desiccation in the San Felipe Hills, Salton Trough, southern Salton Trough, southern California. Geol. Soc. Am. Abstr. Program 37:318.

Lilly, D. R. 2003. Structural geology of a transitory left step in San Felipe Hills fault. MS thesis, San Diego State University, CA.

Lutz, A. T. 2005. Tectonic controls on Pleistocene basin evolution in the central San Jacinto fault zone, southern California. MS thesis, University of Oregon, Eugene.

Lutz, A. T.; Dorsey, R. J.; Housen, B. A.; and Janecke, S. U. 2006. Stratigraphic record of Pleistocene faulting and basin evolution in the Borrego Badlands, San Jacinto fault zone, southern California. Geol. Soc. Am. Bull. 118:1377-1397.

Magistrale, H., and Rockwell, T. 1996. The central and southern Elsinore fault zone, southern California. Bull. Seismol. Soc. Am. 86:1793-1803.

Matti, J. C., and Morton, D. M. 1993. Paleogeographic evolution of the San Andreas fault in southern California: a reconstruction based on a new cross-fault correlation. In Powell, R. E.; Weldon, R. J., II; and Matti, J. C., eds. The San Andreas fault system: displacement, palinspastic reconstruction, and geologic evolution. Geol. Soc. Am. Mem. 178:107-159.

Molnar, P. 2004. Late Cenozoic increase in accumulation rates of terrestrial sediment: how might climate change have affected erosion rates? Annu. Rev. Earth Planet. Sci. 32:67-89.

Morley, E. R. 1963. Geology of the Borrego Mountain quadrangle and the western portion of the Shell Reef quadrangle, San Diego County, California. MS thesis, University of Southern California, Los Angeles.

Morton, D. M., and Matti, J. C. 1993. Extension and contraction within an evolving divergent strike-slip fault complex: the San Andreas and San Jacinto fault zones at their convergence in southern California. In Powell, R. E.; Weldon, R. J.; and Matti, J. C., eds. The San Andreas Fault system: displacement, palinspastic reconstruction, and geologic evolution. Geol. Soc. Am. Mem. 178:217-230.

Mueller, K.; Kier, G.; Rockwell, T.; and Jones, C. H. 2006. Quaternary rift-flank uplift of the Peninsular Ranges in Baja and southern California by removal of mantle lithosphere: RCL-Cortez MARGINS meeting. http://rclcortez.wustl.edu/Presentations/Cortez_Posters/Jones/ Jones_poster_RCLmtg_opt.pdf.

Opdyke, N. D.; Lindsay, E. H.; Johnson, N. M.; and Downs, T. 1977. The paleomagnetism and magnetic polarity stratigraphy of the mammal-bearing section of Anza-Borrego State Park, California. Quat. Res. 7: 316-329.

Oskin, M., and Stock, J. 2003. Marine incursion synchronous with plate-boundary localization in the Gulf of California. Geology 1:23-26.

Plummer, P. S., and Gostin, V. A. 1981. Shrinkage cracks: desiccation or synersis? J. Sediment. Petrol. 51:11471156.

Reitz, D. T. 1977. Geology of the western and central San Felipe Hills, northwestern Imperial County, California. MS thesis, University of Southern California, Los Angeles.

Remeika, P., and Beske-Diehl, S. 1996. Magnetostratigraphy of the western Borrego Badlands, Anza-Borrego Desert State Park, California: implications for stratigraphic age control. In Abbott, P. L., and Seymour, D. C., eds. Sturzstroms and detachment faults, AnzaBorrego Desert State Park, California. South Coast Geological Society annual field trip guide book, no. 24. Santa Ana, CA, South Coast Geological Society, p. 209-220.

Riba, O. 1976. Syntectonic unconformities of the Alto Cardener Spanish Pyrenees: a genetic interpretation. Sediment. Geol. 15:213-233.

Richard, P.; Ballard, J. F.; Colletta, B.; and Cobbold, P. R. 1989. Fault genesis and propagation above a basement strike-slip fault: analogue modeling and tomography. C. R. Acad. Sci. Ser. II Mec. Phys. Chim. Sci. Univers Sci. Terre 309:2111-2118.

Sanders, C. O. 1989. Fault segmentation and earthquake occurrence in the strike-slip San Jacinto fault zone, California. In Schwartz, D. P., and Sibson, R. H., eds. Proceedings of conference XLV: a workshop on fault segmentation and controls of rupture initiation and termination. U.S. Geol. Surv. Open File Rep. 89-0315, p. 324-349.

Savage, J. C., and Prescott, W. H. 1976. Strain accumulation on the San Jacinto fault near Riverside, California. Bull. Seismol. Soc. Am. 66:1749-1754.

Scholz, C. H. 2002. The mechanics of earthquakes and faulting. 2nd ed. Cambridge, Cambridge University Press, $439 \mathrm{p}$.

Sharp, R. V. 1967. San Jacinto fault zone in the Peninsular Ranges of southern California. Geol. Soc. Am. Bull. 78:705-729.

Sheridan, J. M.; Weldon, R. J., II.; Thornton, C. A.; and 
Rymer, M. J. 1994. Stratigraphy and deformational history of the Mecca Hills, southern California. In McGill, S. F., and Ross, T. M., eds. Geological investigations of an active margin. Geological Society of America, Cordilleran Section guidebook. Redlands, CA, San Bernardino County Museum, p. 319-325.

Smith, G. A. 1994. Climatic influences on continental deposition during the late-stage filling of an extensional basin, southeastern Arizona. Geol. Soc. Am. Bull. 106:1212-1228.

Steely, A. N. 2006. Evolution and kinematics of the West Salton detachment fault and its deforming supradetachment basin and the younger cross-cutting San Felipe fault zone. MS thesis, Utah State University, Logan.

Steely, A. N.; Janecke, S. U.; Axen, G.; and Dorsey, R. 2005. Pleistocene ( 1 Ma) transition from West Salton detachment faulting to cross-cutting dextral strikeslip faults in the SW Salton Trough. Geol. Soc. Am. Abstr. Program 37:274.

Steely, A. N.; Janecke, S. U.; and Dorsey, R. I. 2004. Evidence for syn-kinematic deposition and folding of Imperial-age synrift deposits above the West Salton detachment fault: Borrego Mountain area, southern California. Geol. Soc. Am. Abstr. Program 37:317.

Wagoner, J. L. 1977. Stratigraphy and sedimentation of the Pleistocene Brawley and Borrego formations in the San Felipe Hills area, Imperial Valley, California, U.S.A. MS thesis, University of California, Riverside.

Waters, M. R. 1983. Late Holocene lacustrine chronology and archaeology of ancient Lake Cahuilla, California. Quat. Res. 19:373-387.

Weinberger, R. 2001. Evolution of polygonal patterns in stratified mud during desiccation: the role of flaw distribution and layer boundaries. Geol. Soc. Am. Bull. 113:20-31.

Wells, D. L. 1987. Geology of the eastern San Felipe Hills, Imperial Valley, California: implications for wrench faulting in the southern San Jacinto fault zone. MS thesis, San Diego State University, San Diego, CA.

Winker, C. D. 1987. Neogene stratigraphy of the Fish Creek-Vallecito section, southern California: implications for early history of the northern Gulf of California and Colorado delta. PhD dissertation, University of Arizona, Tucson.

Winker, C. D., and Kidwell, S. M. 1986. Paleocurrent evidence for lateral displacement of the Pliocene Colorado River delta by the San Andreas fault system, southeastern California. Geology 14:788-791.

- 1996. Stratigraphy of a marine rift basin: Neogene of the western Salton Trough, California. In Abbot, P. L., and Cooper, J. D., eds. Field conference guide 1996. SEPM (Soc. Econ. Paleontol. Mineral.) Field Trip Guideb. 80:295-336.

- 2002. Stratigraphic evidence for ages of different extensional styles in the Salton Trough, southern California. Geol. Soc. Am. Abstr. Program 34:83-84.

Wright, P. V. 1986. Paleosols: their recognition and interpretation. Princeton, NJ, Princeton University Press, 307 p. 
Copyright of Journal of Geology is the property of University of Chicago Press and its content may not be copied or emailed to multiple sites or posted to a listserv without the copyright holder's express written permission. However, users may print, download, or email articles for individual use. 